\title{
Accessories in Kaiserstuhl carbonatites and related rocks as accurate and faithful recorders of whole rock age and isotopic composition
}

\author{
Mahdi Ghobadi $^{1,2} \cdot$ Gerhard P. Brey $^{2}(1) \cdot$ Axel Gerdes $^{2,3} \cdot$ Heidi E. Höfer $^{2} \cdot$ Jörg Keller $^{4}$
}

Received: 23 April 2021 / Accepted: 29 October 2021 / Published online: 9 December 2021

(c) The Author(s) 2021

\begin{abstract}
The accessories perovskite, pyrochlore, zirconolite, calzirtite and melanite from carbonatites and carbonate-rich foidites from the Kaiserstuhl are variously suited for the in situ determination of their $\mathrm{U}-\mathrm{Pb}$ ages and $\mathrm{Sr}$, Nd- and Hf-isotope ratios by LA-ICP-MS. The ${ }^{143} \mathrm{Nd} /{ }^{144} \mathrm{Nd}$ ratios may be determined precisely in all five phases, the ${ }^{176} \mathrm{Hf} /{ }^{177} \mathrm{Hf}$ ratios only in calzirtite and the ${ }^{87} \mathrm{Sr} /{ }^{86} \mathrm{Sr}$ ratios in perovskites and pyrochlores. The carbonatites and carbonate-rich foidites belong to one of the three magmatic groups that Schleicher et al. (1990) distinguished in the Kaiserstuhl on the basis of their $\mathrm{Sr}, \mathrm{Nd}$ and $\mathrm{Pb}$ isotope ratios. Tephrites, phonolites and essexites (nepheline monzogabbros) form the second and limburgites (nepheline basanites) and olivine nephelinites the third. Our ${ }^{87} \mathrm{Sr} /{ }^{86} \mathrm{Sr}$ isotope data from the accessories overlap with the carbonatite and olivine nephelinite fields defined by Schleicher et al. (1990) but exhibit a much narrower range. These and the $\varepsilon \mathrm{Nd}$ and $\varepsilon \mathrm{Hf}$ values plot along the mantle array in the field of oceanic island basalts relatively close to mid-ocean ridge basalts. Previously reported $\mathrm{K}-\mathrm{Ar}, \mathrm{Ar}-\mathrm{Ar}$ and fission track ages for the Kaiserstuhl lie between 16.2 and 17.8 Ma. They stem entirely from the geologically older tephrites, phonolites and essexites. No ages existed so far for the geologically younger carbonatites and carbonate-rich foidites except for one apatite fission track age (15.8 Ma). We obtained precise $\mathrm{U}-\mathrm{Pb}$ ages for zirconolites and calzirtites of 15.66 , respectively $15.5 \mathrm{Ma}( \pm 0.12 \sigma)$ and for pyrochlores of $15.35 \pm 0.24 \mathrm{Ma}$. Only the perovskites from the Badberg soevite yielded a U-P concordia age of $14.56 \pm 0.86$ Ma while the perovskites from bergalites (haüyne melilitites) only gave ${ }^{206} \mathrm{~Pb} / 238 \mathrm{U}$ and ${ }^{208} \mathrm{~Pb} /{ }^{232} \mathrm{Th}$ ages of $15.26 \pm 0.21$, respectively, $15.28 \pm 0.48 \mathrm{Ma}$. The main Kaiserstuhl rock types were emplaced over a time span of $1.6 \mathrm{Ma}$ almost 1 million years before the carbonatites and carbonate-rich foidites. These were emplaced within only $0.32 \mathrm{Ma}$.
\end{abstract}

Keywords In situ determination of $\mathrm{Sr}, \mathrm{Nd}$ and $\mathrm{Hf}$ isotope ratios · In situ determination of $\mathrm{U}-\mathrm{Pb}$ ages $\cdot$ Accessories in carbonatites · Kaiserstuhl

\section{Introduction}

The relationship between carbonatites and associated alkaline silicate rocks has always been and still is a matter of intense discussion. Most carbonatites that are associated

Gerhard P. Brey

brey@em.uni-frankfurt.de

1 Nordwest Geochemical Consulting Services, Ottawa, ON, Canada

2 Institut Für Geowissenschaften, J.-W. Goethe Universität, Altenhöferallee 1, 60438 Frankfurt, Germany

3 Frankfurt Isotope and Element Research Center (FIERCE), Goethe University Frankfurt, 60438 Frankfurt, Germany

4 Mineralogisch-Petrographisches Institut, Universität, Albertstr. 23b, 7800 Freiburg, Germany with silicate rocks intrude the alkaline silicate rocks (e.g. Bell et al. 1999) and appear to be younger just like in the Kaiserstuhl. Results from experimental petrology and major, trace and isotope geochemistry do not provide a single answer to the generation of carbonatitic magmas but suggest that carbonatitic melts can be generated by partial melting directly from the mantle, by liquid immiscibility and/or fractional crystallization (see Jones et al. 2013 for a more recent review). The isotopic compositions do not unequivocally distinguish between the various possibilities mainly because the silicate rocks vary much wider in composition than the associated carbonatites (see, e.g. Bell 1998, and Gittins and Harmer, 2003). A direct association of carbonatites and silicate rocks is only feasible where they overlap in isotopic composition. The advent of LA-ICP-MS (laser ablation inductively coupled plasma mass spectrometry) made 
the in situ analysis of trace elements and isotope ratios of minerals in polished mounts possible. This opened entirely new opportunities for in situ analysis of accessory minerals especially in carbonatites and alkaline rocks. These contain phases with incompatible trace element concentrations up to the level of major elements. Their in situ analysis is fast and accurate and can substitute conventional whole rock TIMS analysis to quite an extent in cases (e.g. Sylvester 2008). LAICP-MS analyses may even be superior because contamination of whole rocks by meteoric water, etc. is excluded. Perovskite $\left(\mathrm{CaTiO}_{3}\right)$, pyrochlore $\left(\mathrm{Ca}_{2} \mathrm{Nb}_{2} \mathrm{O}_{7}\right)$ and schorlomite (a Ti-rich variety of melanite) already found application (e.g. Kogarko et al. 2009; Mitchell et al. 2011; Yang et al. 2018) while other accessories, especially $\mathrm{Zr-rich}$ phases like zirconolite $\left(\mathrm{CaZrTi}_{2} \mathrm{O}_{7}\right)$ and calzirtite $\left(\mathrm{Ca}_{2} \mathrm{Zr}_{5} \mathrm{Ti}_{2} \mathrm{O}_{16}\right)$ still need more investigation ( $\mathrm{Wu}$ et al. 2010). The latter phases are scarce in alkaline rocks and carbonatites; they have, however, great potential for in situ U-Pb geochronology and the determination of the ( $\mathrm{Rb})-\mathrm{Sr}, \mathrm{Sm}-\mathrm{Nd}$ and $\mathrm{Lu}-\mathrm{Hf}$ isotope systems (e.g. Rasmussen and Fletcher 2004; Wu et al. 2011).

The aim of the present study is to test and further explore the potential and proficiency for in-situ laser ablation analysis of five accessory phases from carbonatites and carbonaterich foidites, i.e. of perovskite, pyrochlore, calzirtite, zirconolite and melanite (andradite-rich garnet). These accessory phases were separated from intrusive, massive carbonatites and from carbonatite and bergalite dikes (haüyne melilitites-Braunger et al. 2018) from the young volcanic edifice Kaiserstuhl in the Rhine Graben in Germany. Known ages for the silicate-based intrusives and extrusives range between 16 and $18 \mathrm{Ma}$. Ages for the carbonatites and bergalites were not known before except for one apatite fission track age of 15.8 Ma from a carbonatite (Wagner 1976). In agreement with the geological findings absolute ages of the carbonatites and related rocks should be younger than those of the main edifice-building rocks of the Kaiserstuhl-by how much was not known before the present study. We evaluate the precision and accuracy of the mineral isotope compositions in comparison to conventional whole rock analyses and of the $\mathrm{U}-\mathrm{Pb}$ geochronology in comparison to $\mathrm{K}-\mathrm{Ar}, \mathrm{Ar}-\mathrm{Ar}$ and fission track ages. The new data should give tighter constraints on age and genetic relationships of the diverse rock types of the Kaiserstuhl complex.

\section{General geology of the Kaiserstuhl}

The Miocene Kaiserstuhl alkaline complex (Fig. 1a) is located in the SW of Germany, in the southern part of the Rhine rift valley. Wimmenauer (1966) and Keller (1984a, b) distinguished five rock groups (Fig. 1b) on the basis of petrography and major element anlysis: (1) olivine nephelinites and limburgites (ne-basanites), (2) tephrites and essexites (renamed to nepheline monzogabbro by Braunger et al., 2018) as the dominant rock types of the complex, (3) phonolites, (4) a group of bergalites and hauynophyres, both considered as a petrogenetic links between carbonatites and the alkaline rocks and (5) carbonatites. Carbonatites, bergalites and related rocks intrude all other silicate rock types and are, therefore, geologically younger (Fig. 2b). The carbonatites occur in three forms: soevites (intrusive bodies of calcite carbonatite; Wimmenauer 1966), alvikites
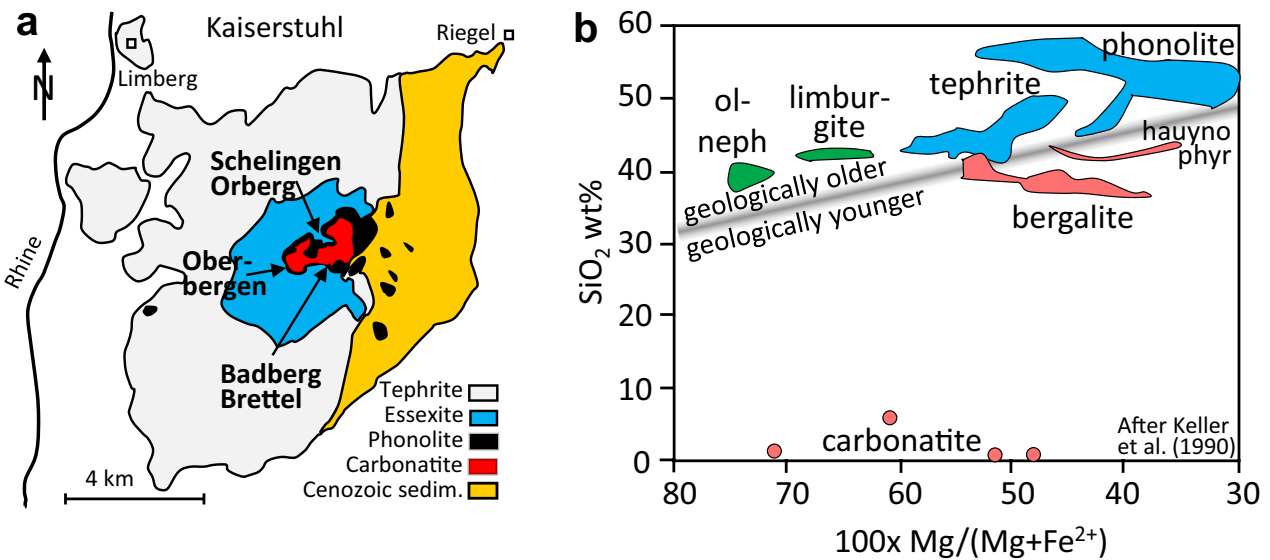

Fig. 1 a Simplified geological map of the Kaiserstuhl after Wimmenauer (2003); essexites are the subvolcanic equivalents to tephrites $\mathbf{b}$ overview on Kaiserstuhl rock types with the division into five groups (olivine nephelinites + limburgites, tephrites, phonolite, bergalites + hauynophrs and carbonatites after Wimmenauer (1966) and Keller (1984a, b). The colour coding corresponds to the three groups that were distinguished by Schleicher et al. (1990) on the basis of

Sr-, Nd- and Pb-isotope ratios. The fields in the figure correspond to those in Fig. 11 of Keller et al. (1990) with carbonatite compositions added from their Table 8. The field of olivine nephelinites contains one specimen directly from the Kaiserstuhl and four from its immediate surroundings. A much more comprehensive data set on whole rock major and trace elements from the Kaiserstuhl can be found in Braunger et al. (2018) 

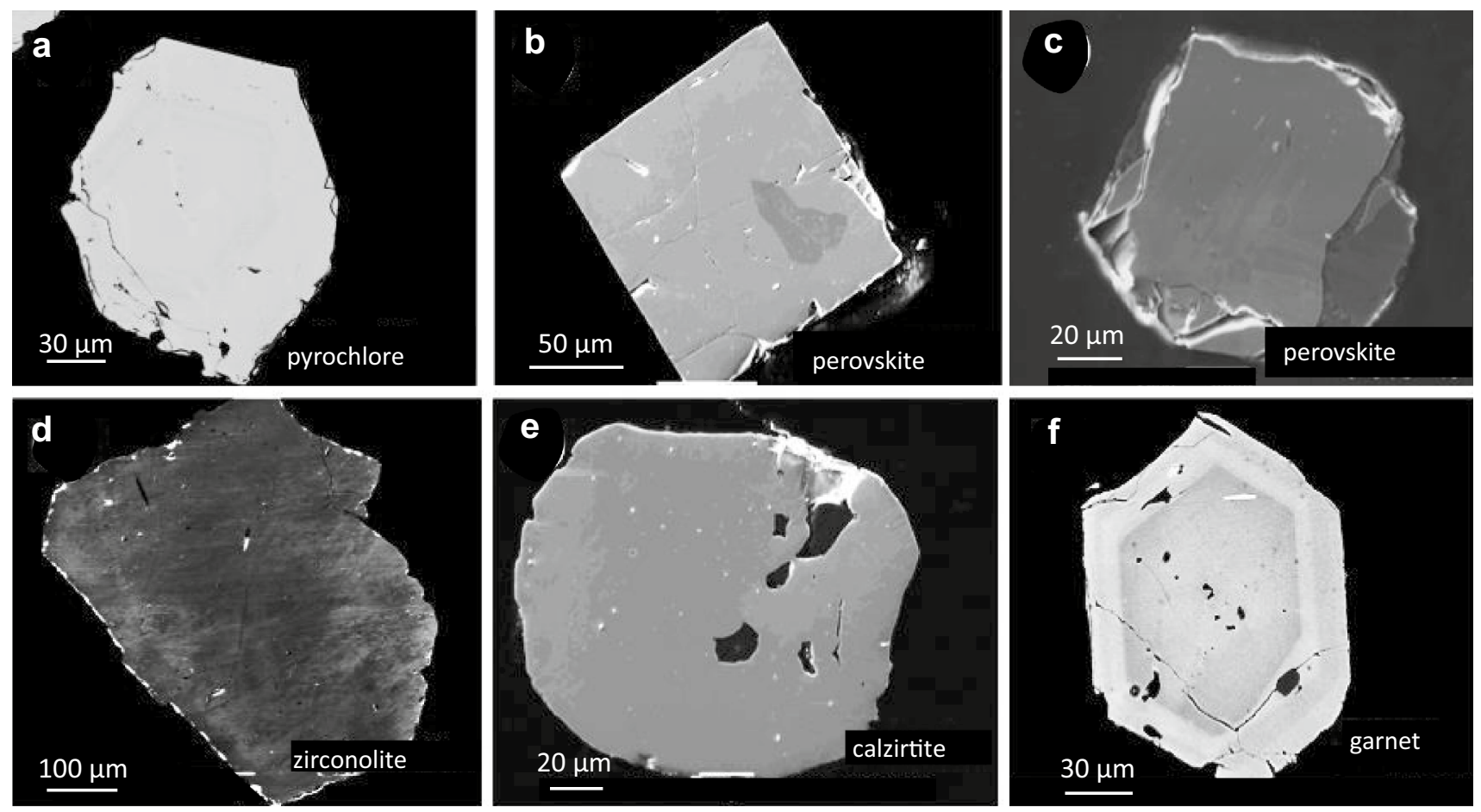

Fig. 2 Secondary Electron Images (SEI) of a pyrochlore from soevite, $\mathbf{b}$ perovskite from soevite, $\mathbf{c}$ perovskite from bergalite, $\mathbf{d}$ zirconolite and $\mathbf{e}$ calzirtite from alvikite, and $\mathbf{f}$ melanite from alvikite

(calcite carbonatite dykes; Lehnert 1989) and lapilli tuffs (Keller 1981, 1989). Keller (1984a) distinguished a Narich $\left(\mathrm{K}_{2} \mathrm{O} / \mathrm{Na}_{2} \mathrm{O}<0.8\right)$ and $\mathrm{K}$-rich $\left(\mathrm{K}_{2} \mathrm{O} / \mathrm{Na}_{2} \mathrm{O}>0.8\right)$ series. Olivine nephelinites, limburgites, bergalites and hauynophyres belong to the former series, tephrites, phonolites and essexites to the latter. Based on whole rock Sr-, Nd- and $\mathrm{Pb}$-isotope ratios Schleicher et al. (1990) distinguished olivine nephelinites and limburgites as one group with the most positive $\varepsilon N d$ values, bergalites, hauynophyres and carbonatites as a second group with less positive $\varepsilon \mathrm{Nd}$ but similarly low ${ }^{87} \mathrm{Sr} /{ }^{86} \mathrm{Sr}$ ratios and tephrites, phonolites and essexites with highest ${ }^{87} \mathrm{Sr}^{86} \mathrm{Sr}$ ratios as a third group. The differences were interpreted such that olivine nephelinites, carbonatites and related foidites stem from a similar mantle source with no modification of the isotopic composition by subsequent processes and that the tephrite to phonolite family stems from another mantle source with modification of the isotopic composition by crustal processes. Essentially the same distinction was made by Wang et al. (2014) and Braunger et al. (2018) whereby several rock types were renamed to correspond to modern nomenclature. The latter authors argue that rare basanitic lamprophyres (monchiquites) are the primitive rock types for the tephritic to phonolitic group and that olivine melilititic magmas are the primary magmas for the other group. They model the derivation of the differentiated magmas by fractional crystallization accompanied by an increase in oxygen fugacity. The Miocene age of the
Kaiserstuhl complex with ages between 16 and 18 Ma has been established with bulk rock $\mathrm{K}-\mathrm{Ar}$ and $\mathrm{Ar}-\mathrm{Ar}$ age determinations and the fission track method in the main silicate rock types by Lippolt et al. (1963), Wagner (1976), Baranyi et al. (1976), Schleicher (1986) and Kraml et al. (2006).

\section{Analytical methods}

The samples for this study (Table 1) are from the Freiburg collection of Prof. J. Keller. They stem from the central intrusive carbonatites (soevites from the Orberg at Schelingen and the Badberg, Fig. 1) and from alvikite and bergalite dykes in the intrusive center $\mathrm{W}$ of Badberg (Brettel gang group). Soevites are calcitic intrusive carbonatites, alvikites are fast quenched calcitic dyke rocks and bergalites are calcite-rich melilititic dyke rocks (renamed by Braunger et al. 2018 as haüyne melilitite). The Schelingen soevite consists of calcite up to $30 \mathrm{~cm}$, magnetite, almost pure forsterite, Ba-phlogopite, apatite and pyrochlore. The Badberg soevite consist of coarse-grained calcites with Ba-phlogopite, magnetite and apatite and pyrochlore, $\mathrm{Nb}$-perovskite and lattrapite (perovskite-lueshite group, $\mathrm{CaTiO}_{3}-\mathrm{NaNbO}_{3}$ with $\left.\mathrm{Fe}_{2} \mathrm{O}_{3} \ldots\right)$ as accessories. Alvikites from the Brettel dike system have (comb-layered) calcite (Katz and Keller 1981) as their main phase with perovskite, pyrochlore, zirconolite, calzirtite and melanite as accessories. The bergalite dikes 
Table 1 Overview on localities and mineral separates

\begin{tabular}{llll}
\hline Sample number & Rock type & Locality & Minerals separated \\
\hline S10208/S10209 & Sövite & Badberg & Nb-perovskite \\
S10223/KK680 & Sövite & Orberg (Schelingen) & Pyrochlore \\
K219xx & Alvikite & Brettel dyke & Perovskite, pyrochlore, \\
& & & $\begin{array}{l}\text { andradite, calzirtite, } \\
\text { zirconolite }\end{array}$ \\
K217/K417 & Bergalite & Brettel; Badberg & Perovskite \\
\hline
\end{tabular}

from Oberbergen consist of hauyne, melilite, perovskite, nepheline, calcite, mica, magnetite and apatite. The Brettel carbonatite dike contains rounded calcites up to $2 \mathrm{~cm}$ and magnetite up to $1 \mathrm{~cm}$ and olivine, zirconolite, calzirtite, pyrochlore, $\mathrm{Nb}$-perovskite and baddeleyte. More details of all rock types are described in Keller et al. (1990).

The samples were first placed into cold $2.5 \mathrm{M} \mathrm{HCl}$ to dissolve the carbonates. The undissolved rest was sieved and sorted according to their magnetic and gravitational properties. The non-magnetic and heavy fractions were hand-picked for accessory minerals (see Table 1). The handpicked minerals were embedded in epoxy and polished. Grain sizes varied between 100 and $200 \mu \mathrm{m}$ (see secondary electron images, Fig. 2). Generally, one analysis was performed on each individual grain with a laser spot size varying between 20 to $100 \mu \mathrm{m}$. Multiple grains were analysed for each mineral species to test for compositional variation, isotopic homogeneity and to obtain a high precision by statistics for isotope analysis and $\mathrm{U}-\mathrm{Pb}$ age determination. Prior to analysis, the polished minerals were characterized by secondary electron (SE), back scattered electron (BSE) and cathodoluminescence (CL) imaging with an electron microscope (JEOL JSM 6490) to identify and avoid altered or fractured areas and mineral inclusions during LA-ICP-MS analysis (Fig. 2). All analyses were performed at the Institut für Geowissenschaften of the Goethe University, Frankfurt am Main.

\section{Major and trace element analyses}

The major elements were analyzed with an Electron Microprobe (JEOL JXA-8900RL) at the Goethe University, Frankfurt am Main. The analyses were carried out in WDS (Wavelength Dispersive Spectroscopy) mode with an accelerating voltage of $15 \mathrm{kV}$, a beam current of $20 \mathrm{nA}$ and a spot size of $10 \mu \mathrm{m}$. The counting time was $30 \mathrm{~s}$ with a background measurement time from 10 to $30 \mathrm{~s}$ depending on the element. The standards were natural minerals and metals; a ZAF correction was employed to the raw data. For the elevated abundances of REE, $U$ and Th in pyrochlores, we had to perform an off-line ZAF correction using the abundances of trace elements (such as $\mathrm{Th}, \mathrm{Ce}$ and $\mathrm{U}$ ) obtained from laser ablation ICP MS.
The trace elements were analyzed using an Element 2 sector field ICP MS, Thermo Finnigan, coupled to a RESOLution M-50 Excimer (193 nm) laser from Resonetics. Helium (about $0.6 \mathrm{l} / \mathrm{min}$ ) was used as carrier gas in the two-volume ablation cell and was mixed with about $0.8 \mathrm{l} / \mathrm{min} \mathrm{Ar}$, and $5 \mathrm{ml} / \mathrm{min} \mathrm{N}_{2}$ after the cell and before introduction into the plasma. Depending on the size and element concentration of the grains, the laser spot size was varied from 20 to $60 \mu \mathrm{m}$ with a fluence of $3-4 \mathrm{~J} / \mathrm{cm}^{2}$ and a repetition rate of $5-10 \mathrm{~Hz}$. The ablation time was $33 \mathrm{~s}$ with $20 \mathrm{~s}$ for background measurements. The following isotopes were analyzed for determining the abundances of trace/major elements: ${ }^{29} \mathrm{Si},{ }^{31} \mathrm{P}$, ${ }^{44} \mathrm{Ca},{ }^{45} \mathrm{Sc},{ }^{47} \mathrm{Ti},{ }^{85} \mathrm{Rb},{ }^{88} \mathrm{Sr},{ }^{89} \mathrm{Y},{ }^{90} \mathrm{Zr},{ }^{93} \mathrm{Nb},{ }^{137} \mathrm{Ba},{ }^{139} \mathrm{La}$, ${ }^{140} \mathrm{Ce},{ }^{141} \mathrm{Pr},{ }^{146} \mathrm{Nd},{ }^{147} \mathrm{Sm},{ }^{151} \mathrm{Eu},{ }^{157} \mathrm{Gd},{ }^{159} \mathrm{~Tb},{ }^{161} \mathrm{Dy},{ }^{165} \mathrm{Ho}$, ${ }^{167} \mathrm{Er},{ }^{169} \mathrm{Tm},{ }^{172} \mathrm{Yb},{ }^{175} \mathrm{Lu},{ }^{178} \mathrm{Hf},{ }^{181} \mathrm{Ta},{ }^{208} \mathrm{~Pb},{ }^{232} \mathrm{Th}$, and ${ }^{238} \mathrm{U}$. Data were reduced offline using GLITTER 4.0 (Griffin et al. 2008) with ${ }^{44} \mathrm{Ca}$ for internal standardization and NIST SRM612 soda lime glass as the external calibration standard. The signal intensities were corrected for the gas blank background and the final element concentrations were calculated by comparing the Ca-normalized signals of the internal standard with that of the NIST SRM612 glass following Pearce et al. (1997). The Ca content of each mineral was determined beforehand by electron microprobe analysis (EPMA).

\section{In situ analysis of Sr-, Nd- and Hf-isotopes}

The isotope analyses were performed using a Thermo Finnigan Neptune MC-ICP-MS equipped with 9 Faraday detectors and attached to a RESOLution M-50 excimer laser (193 nm) from Resonetics. The laser spot size was varied from 45 to $100 \mu \mathrm{m}$ with a fluence of $1.5 \mathrm{~J} / \mathrm{cm}^{2}$, using a repetition rate of $6 \mathrm{~Hz}$.

Sr-isotope analyses were carried out on perovskites and pyrochlores. The isotope ratios were measured in a static multi-collector mode with $60 \mathrm{~s}$ ablation time for 30 integrated blocks using a cup configuration as suggested by Ramos et al. (2004). The nine Faraday detectors were set to measure the isotopes from ${ }^{83} \mathrm{Kr}$ to ${ }^{88} \mathrm{Sr}$ with monitoring the masses $83.5,85.5$ and 86.5 to evaluate double charged ions of ${ }^{167} \mathrm{Er}^{2+},{ }^{171} \mathrm{Yb}^{2+}$ and ${ }^{173} \mathrm{Yb}^{2+}$ respectively. At high abundance levels of the HREE different double charged $\mathrm{Yb}$ and 
Er isotopes interfere with $\mathrm{Sr}$ and $\mathrm{Rb}$ isotope masses: ${ }^{168} \mathrm{Er}$ and ${ }^{168} \mathrm{Yb}$ on ${ }^{84} \mathrm{Sr},{ }^{170} \mathrm{Er}$ on ${ }^{85} \mathrm{Sr}$ and ${ }^{85} \mathrm{Rb},{ }^{172} \mathrm{Yb}$ on ${ }^{86} \mathrm{Sr}$, ${ }^{174} \mathrm{Yb}$ on ${ }^{87} \mathrm{Sr}$ and ${ }^{87} \mathrm{Rb}$ and finally ${ }^{176} \mathrm{Yb}$ on ${ }^{88} \mathrm{Sr}$. These interferences were estimated from the background-corrected signals on masses $83.5,85.5$ and 86.5 and the ratios of ${ }^{168} \mathrm{Er} /{ }^{167} \mathrm{Er},{ }^{164} \mathrm{Er} /{ }^{167} \mathrm{Er},{ }^{166} \mathrm{Er} /{ }^{167} \mathrm{Er},{ }^{170} \mathrm{Er} /{ }^{167} \mathrm{Er},{ }^{168} \mathrm{Yb} /{ }^{173} \mathrm{Yb}$, ${ }^{172} \mathrm{Yb} /{ }^{173} \mathrm{Yb}$, and ${ }^{174} \mathrm{Yb} /{ }^{173} \mathrm{Yb}$. Gas blanks were measured frequently throughout the sequence to monitor $\mathrm{Kr}$ and other possible interferences on the selected mass range. The gas blank was subtracted directly from the signal of each individual analysis prior to interference and mass bias correction. For correction of the $\mathrm{Rb}$ interference on mass 87 , we monitored ${ }^{85} \mathrm{Rb}$ and used the natural ${ }^{87} \mathrm{Rb} /{ }^{86} \mathrm{Rb}$ ratio of 0.38564 , the respective $\mathrm{Sr}$ mass bias $\left(\beta \mathrm{Sr}={ }^{86} \mathrm{Sr} /{ }^{88} \mathrm{Sr}_{\text {measured }}\right.$ relative to $\left.{ }^{86} \mathrm{Sr} /{ }^{88} \mathrm{Sr}_{\text {true }} ; 0.1194\right)$ and a $\beta \mathrm{Rb} / \beta \mathrm{Sr}$ correction factor $(\sim 0.93)$. The latter was empirically determined $\left({ }^{87} \mathrm{Rb} /{ }^{85} \mathrm{Rb}\right.$ mass bias $/{ }^{86} \mathrm{Sr} /{ }^{88} \mathrm{Sr}$ mass bias $)$ from soda-lime glass SRM-NIST610 (interference of ${ }^{87} \mathrm{Rb}$ on ${ }^{87} \mathrm{Sr}>300 \%$; ${ }^{87} \mathrm{Sr} /{ }^{86} \mathrm{Sr} \sim 0.709$ ) analyses at the beginning of the analytical session. Due to the low abundances of $\mathrm{Rb}$ and the high $\mathrm{Sr}$ contents, the interferences of ${ }^{87} \mathrm{Rb}$ on ${ }^{87} \mathrm{Sr}$ were negligible in most cases. The monitored ${ }^{83} \mathrm{Kr}$, after ${ }^{166} \mathrm{Er}$ interference subtraction, was used to check the potential interferences of Ca dimers (e.g., ${ }^{43} \mathrm{Ca}^{40} \mathrm{Ca}$ ) and $\mathrm{Ca}$ argides (e.g., ${ }^{44} \mathrm{Ca}^{40} \mathrm{Ar}$ ). However, as shown before (Ramos et al. 2004; Vroon et al. 2008; Wu et al. 2011) no interferences were imposed and a correction was not necessary. For Sr mass bias correction, an exponential law was used, assuming the natural ratio of ${ }^{86} \mathrm{Sr} /{ }^{88} \mathrm{Sr}=0.1194$. For the HREE mass bias, we used a $B$ factor of 1.31 as obtained from the analysis of $\mathrm{Yb}$ isotopes in zircon. To monitor the accuracy and reproducibility of our method, we used in house standard plagioclase megacrysts from the Miringa volcano (Biu plateau, Nigeria; named Mir' a) and Mir' b), previously analyzed by IDFTIMS (Rankenburg, 2004). Our measurements during several separate sessions yielded ${ }^{87} \mathrm{Sr} /{ }^{86} \mathrm{Sr}$ ratios of $0.703043 \pm 0.00029(n=4)$ and $0.703087 \pm 0.000024(n=12)$, respectively. The values given by Rankenburg et al. (2004) are 0.703096 respectively 0.703044 . For instrumental mass bias correction, we used the exponential law assuming the natural ratio for ${ }^{86} \mathrm{Sr} /{ }^{88} \mathrm{Sr}$ of 0.1194 .

The Sm-Nd- isotopes were analyzed in perovskite, pyrochlore, zirconolite, calzirtite and melanite. Data were collected in static mode using nine faraday cups for monitoring ${ }^{142} \mathrm{Nd},{ }^{143} \mathrm{Nd},{ }^{144} \mathrm{Nd},{ }^{145} \mathrm{Nd},{ }^{146} \mathrm{Nd},{ }^{147} \mathrm{Sm},{ }^{148} \mathrm{Nd}$, ${ }^{149} \mathrm{Sm},{ }^{150} \mathrm{Nd}$ with an ablation time of $62 \mathrm{~s}$ for integrating 60 blocks. The only significant interference for $\mathrm{Nd}$-isotope analysis is ${ }^{144} \mathrm{Sm}$ on ${ }^{144} \mathrm{Nd}$, while the effect of the other isobaric mass (i.e.: ${ }^{142} \mathrm{Ce}$ on ${ }^{142} \mathrm{Nd}$ ) is negligible. For mass bias correction, the exponential law was applied, using the natural ${ }^{146} \mathrm{Nd} /{ }^{144} \mathrm{Nd}$ ratio of 0.72190 . The results were then normalized to an off-set correction factor, calculated from the deviation of the measured in-house standard from its accepted values. We used Merck $500 \mathrm{ppb}$ as our in-house standard and obtained an average of $0.511722( \pm 0.000002$, $n=2$ ) for ${ }^{143} \mathrm{Nd} /{ }^{144} \mathrm{Nd}$. NIST 610 was measured several times to monitor instrumental offset. During two sessions we obtained ${ }^{146} \mathrm{Nd} /{ }^{144} \mathrm{Nd}=0.511912 \pm 0.000035(n=6)$ and $0.511931 \pm 0.000018(n=15)$. These values are close the value of 0.511908 ) suggested by Foster and Vance (2006). If necessary, a small correction was performed to account for the offset between our analyses and the accepted value.

The Hf isotopes were determined in calzirtites from alvikites. The masses ${ }^{172} \mathrm{Yb},{ }^{173} \mathrm{Yb},{ }^{175} \mathrm{Lu},{ }^{176} \mathrm{Hf},{ }^{177} \mathrm{Hf},{ }^{178} \mathrm{Hf}$, ${ }^{179} \mathrm{Hf},{ }^{180} \mathrm{Hf}$ and ${ }^{181}$ Ta were measured in static mode on 9 detectors with $58 \mathrm{~s}$ ablation time, integrating 55 blocks. All analytical and correction procedures are described in detail by Gerdes and Zeh (2009). The isobaric interferences on ${ }^{176} \mathrm{Hf}$ by ${ }^{176} \mathrm{Yb}$ and ${ }^{176} \mathrm{Lu}$ were corrected by monitoring the masses ${ }^{172} \mathrm{Yb},{ }^{173} \mathrm{Yb}$ and ${ }^{175} \mathrm{Lu}$ and calculating ${ }^{176} \mathrm{Yb}$ and ${ }^{176} \mathrm{Lu}$ with using the ratios ${ }^{176} \mathrm{Lu} /{ }^{175} \mathrm{Lu}=0.02658$ and ${ }^{176} \mathrm{Yb} /{ }^{173} \mathrm{Yb}=0.795015$ (both GUF in house values; Gerdes and Zeh, 2009). Instrumental bias correction was by exponential law using ${ }^{179} \mathrm{Hf} /{ }^{177} \mathrm{Hf}=0.7325$ (Patchett and Tatsumoto, 1980). Because of the low abundances of Lu in calzirtites (Table 2), the interference of ${ }^{176} \mathrm{Lu}$ was negligible. For instrumental offset correction we used GJ1 as our reference and measured it twice before, during and after our analytical sequence. The average of ${ }^{176} \mathrm{Hf} /{ }^{177} \mathrm{Hf}(\mathrm{t}) \mathrm{d}$ for our internal standard (GJ1) during measurement is $0.282000 \pm 16(2 \sigma$, $n=6)$, which was adapted to $0.282003 \pm 18(2 \sigma)$ as obtained by Gerdes and Zeh (2009).

\section{Sr- and Nd-isotope dilution analysis}

As a comparison for LA-ICP-MS analysis about $7.7 \mathrm{mg}$ of perovskites and $1.69 \mathrm{mg}$ of pyrochlores were handpicked from the Badberg respectively Schelingen soevites and each divided into two beakers. The grains were first leached in $6 \mathrm{M} \mathrm{HCl}$ at room temperature in an ultrasonic bath and afterwards washed with MQ water twice, each time for about $20 \mathrm{~min}$. Prior to dissolution, a ${ }^{149} \mathrm{Sm}:{ }^{150} \mathrm{Nd}$ double spike was added. The minerals were dissolved in $100 \mu \mathrm{l}$ of $\mathrm{HF}: \mathrm{HNO}_{3}$ (3:1) on a hot plate at $120{ }^{\circ} \mathrm{C}$ for one day. Just before entire evaporation, $100 \mu \mathrm{l}$ of perchloric acid ( $\mathrm{HClO} 4)$ was added to each beaker at a temperature set to $150{ }^{\circ} \mathrm{C}$ for one day. After evaporation to dryness $0.5 \mathrm{ml}$ of $6 \mathrm{M} \mathrm{HCl}$ was added to each beaker at a temperature of $130{ }^{\circ} \mathrm{C}$ for one day. The procedure was repeated a second time. Finally $1 \mathrm{ml}$ of $2 \mathrm{M}$ $\mathrm{HCl}$ was added to each beaker for preparing the samples for $\mathrm{Sr}$ and Sm:Nd chromatographic separation. Sr and LREE were separated using the following chromatographic procedure: after washing out most major and minor elements with $3 \mathrm{ml}$ of $2.2 \mathrm{M} \mathrm{HCl}, \mathrm{Sr}$ and LREE were separated by $6 \mathrm{ml}$ of $3 \mathrm{M} \mathrm{HCl}$ and $10 \mathrm{ml} 6 \mathrm{M} \mathrm{HCl}$, respectively, using cation exchange resin (column 1, Bio Rad 50Wx8); the Nd and Sm 
Table 2 Major and trace elements of mineral separates: Per 01 and $03=$ perovskites from sövite; Per04 and 05 from alvikite; PerB01, $\mathrm{B} 10$ and $\mathrm{B} 26=$ from bergalite; Pyr01, 02 and $03=$ pyrochlores from sövite; Zrct01, 02 and 03 = zirconolites from alvikite; Calz01, 02 and $03=$ calzirtites from alvikite; Grt01, 02 and $03=$ andradites from alvikite

\begin{tabular}{|c|c|c|c|c|c|c|c|c|c|c|}
\hline & Per01 & Per03 & Per04 & Per05 & PerB01 & PerB10 & PerB26 & Pyr01 & Pyr02 & Pyr03 \\
\hline $\mathrm{CaO}$ & 31.6 & 32.3 & 37.55 & 38.17 & 36.31 & 35.89 & 36.25 & 17.9 & 17.2 & 17.6 \\
\hline $\mathrm{Na}_{2} \mathrm{O}$ & 2.9 & 2.4 & 0.73 & 0.71 & 0.57 & 0.66 & 0.82 & 3.6 & 4.5 & 3.71 \\
\hline $\mathrm{TiO}_{2}$ & 35.1 & 38.06 & 52.43 & 54.7 & 52.94 & 51.85 & 53 & 0.35 & 0.88 & 0.45 \\
\hline $\mathrm{FeO}$ & 4.7 & 4.1 & 2.09 & 1.18 & 2.05 & 2.18 & 1.85 & 0.98 & 1.1 & 1.31 \\
\hline $\mathrm{MgO}$ & 0.2 & 0.2 & b.d & 0.02 & 0.017 & 0.014 & 0.01 & 0.6 & 0.4 & 0.57 \\
\hline $\mathrm{Nb}_{2} \mathrm{O}_{5}$ & 18.9 & 16.4 & 3.23 & 1.79 & 1.77 & 2.39 & 2.66 & 60.6 & 61.1 & 59.9 \\
\hline $\mathrm{SiO}_{2}$ & b.d & b.d & b.d & b.d & 0.025 & 0.02 & 0.026 & b.d & b.d & b.d \\
\hline $\mathrm{ZrO}_{2}$ & 0.18 & 0.12 & 0.14 & 0.02 & 0.043 & 0.027 & 0.09 & 2.9 & 2.9 & 2.9 \\
\hline $\mathrm{Ta}_{2} \mathrm{O}_{5}$ & 1.96 & 2.06 & 0.18 & 0.12 & 0.15 & 0.251 & 0.115 & 0.07 & 0.09 & 0.07 \\
\hline $\mathrm{Al}_{2} \mathrm{O}_{3}$ & b.d & b.d & 0.31 & 0.23 & 0.354 & 0.302 & 0.22 & b.d & b.d & b.d \\
\hline F & b.d & b.d & b.d & b.d & b.d & b.d & b.d & 2.3 & 2.8 & 2.3 \\
\hline Total & 95.6 & 95.6 & 96.7 & 96.9 & 94.22 & 93.58 & 95.04 & 89.3 & 90.97 & 88.9 \\
\hline $\mathrm{Ba}$ & 267 & 69 & 291 & 49 & 15 & 24 & 12 & 148 & 216 & 224 \\
\hline $\mathrm{Rb}$ & 1.39 & 0.2 & 0.3 & 0.2 & 9 & 1 & 1 & 0.2 & 0.5 & 0.6 \\
\hline $\mathrm{Sr}$ & 2094 & 2037 & 3412 & 2320 & 4995 & 4267 & 3177 & 2092 & 1520 & 1489 \\
\hline $\mathrm{La}$ & 6333 & 6140 & 8748 & 7178 & 9242 & 9124 & 7335 & 7258 & 10,995 & 10,926 \\
\hline $\mathrm{Ce}$ & 10,158 & 10,601 & 13,808 & 13,126 & 16,379 & 18,067 & 15,729 & 33,443 & 48,094 & 51,103 \\
\hline $\operatorname{Pr}$ & 1230 & 1238 & 1137 & 1641 & 1629 & 1674 & 1596 & 2412 & 3986 & 4102 \\
\hline $\mathrm{Sm}$ & 439 & 423 & 481 & 957 & 633 & 616 & 538 & 1134 & 2151 & 2130 \\
\hline $\mathrm{Nd}$ & 4282 & 4188 & 3711 & 6474 & 5425 & 5440 & 5000 & 9344 & 14,061 & 14,472 \\
\hline $\mathrm{Yb}$ & 15 & 13 & 30 & 40 & 17 & 14 & 12 & 85 & 166 & 190 \\
\hline $\mathrm{Lu}$ & 1 & 1 & 22 & 45 & 2 & 1 & 1 & 7 & 14 & 17 \\
\hline $\mathrm{Hf}$ & 17 & 11 & 7 & 2.8 & 8 & 7 & 6 & 67 & 131 & 126 \\
\hline $\mathrm{U}$ & 104 & 89 & 592 & 334 & 155 & 124 & 104 & 122 & 270 & 261 \\
\hline Th & 90 & 85 & 948 & 1332 & 1828 & 1766 & 1717 & 709 & 2159 & 2011 \\
\hline \multirow[t]{2}{*}{$\mathrm{Pb}$} & 30 & 5.41 & 67 & 10 & 21 & 8 & 7 & 39 & 81 & 37 \\
\hline & Zrct01 & Zrct02 & Zrct03 & & Calz01 & Calz02 & Calz03 & Grt01 & Grt02 & Grt03 \\
\hline $\mathrm{CaO}$ & 11.7 & 12.1 & 12.1 & & 12.02 & 12.31 & 12.43 & 32.6 & 32.6 & 32.8 \\
\hline $\mathrm{Na}_{2} \mathrm{O}$ & 0.0 & 0.0 & 0.0 & & 0.07 & 0.12 & 0.08 & 0.1 & 0.16 & 0.1 \\
\hline $\mathrm{TiO}_{2}$ & 19.3 & 19.9 & 20.0 & & 11.57 & 11.71 & 12.22 & 6.13 & 6.5 & 3.3 \\
\hline $\mathrm{FeO}$ & 7.6 & 7.5 & 7.5 & & 2 & 1.8 & 1.68 & 21 & 21.8 & 22.5 \\
\hline $\mathrm{MgO}$ & 0.6 & 0.6 & 0.5 & & 0.33 & 0.28 & 0.28 & 0.55 & 0.56 & 0.35 \\
\hline $\mathrm{Nb}_{2} \mathrm{O}_{5}$ & 11.8 & 11.9 & 12.0 & & 4.88 & 4.69 & 4.05 & b.d & b.d & b.d \\
\hline $\mathrm{SiO}_{2}$ & 0.1 & 0.1 & 0.1 & & b.d & b.d & 0.01 & 33.4 & 33.5 & 35.5 \\
\hline $\mathrm{ZrO}_{2}$ & 31.5 & 32.7 & 33.3 & & 63.03 & 64.59 & 65.39 & b.d & b.d & b.d \\
\hline $\mathrm{Ta}_{2} \mathrm{O}_{5}$ & 4.2 & 4.0 & 3.9 & & 2.22 & 2.24 & 2.06 & b.d & b.d & b.d \\
\hline $\mathrm{Al}_{2} \mathrm{O}_{3}$ & 0.4 & 0.5 & 0.4 & & 0.27 & 0.21 & 0.3 & 3.3 & 2.4 & 3 \\
\hline F & b.d & b.d & b.d & & 0.27 & 0.25 & 0.21 & 0.7 & 0.7 & 0.9 \\
\hline Total & 87.2 & 89.2 & 89.7 & & 96.7 & 98.2 & 98.7 & 97.7 & 98.2 & 98.4 \\
\hline $\mathrm{Ba}$ & 8 & 4 & 3 & & 2.2 & 1.6 & 91 & 2 & 20 & 4.8 \\
\hline $\mathrm{Rb}$ & 1 & 1 & 1 & & 0.4 & 0.3 & 0.7 & 0.1 & 0.16 & 1.9 \\
\hline $\mathrm{Sr}$ & 87 & 119 & 82 & & 37 & 37 & 70 & 54 & 84 & 89 \\
\hline $\mathrm{La}$ & 1856 & 2920 & 2186 & & 132 & 89 & 137 & 106 & 97 & 120 \\
\hline $\mathrm{Ce}$ & 9487 & 13,339 & 11,576 & & 645 & 450 & 565 & 681 & 549 & 638 \\
\hline $\operatorname{Pr}$ & 1448 & 2201 & 1685 & & 120 & 89 & 81 & 134 & 99 & 115 \\
\hline $\mathrm{Sm}$ & 1542 & 1770 & 1750 & & 230 & 167 & 147 & 139 & 85 & 98 \\
\hline $\mathrm{Nd}$ & 6810 & 8606 & 7880 & & 733 & 539 & 491 & 713 & 491 & 565 \\
\hline
\end{tabular}


Table 2 (continued)

\begin{tabular}{llllllllll}
\hline & Zrct01 & Zrct02 & Zrct03 & Calz01 & Calz02 & Calz03 & Grt01 & Grt02 & Grt03 \\
\hline $\mathrm{Yb}$ & 290 & 290 & 318 & 249 & 211 & 210 & 29 & 13 & 15 \\
$\mathrm{Lu}$ & 34 & 42 & 38 & 23 & 19 & 204 & 4 & 2 \\
$\mathrm{Hf}$ & 528 & 705 & 645 & 1158 & 1063 & 1477 & 14 & 13 \\
$\mathrm{U}$ & 31,136 & 37,573 & 40,986 & 2640 & 2307 & 2718 & 26 & 26 & 33 \\
$\mathrm{Th}$ & 29,993 & 20,365 & 36,262 & 943 & 428 & 325 & 38 & 45 \\
$\mathrm{~Pb}$ & 56 & 29 & 67 & 14 & 12 & 17 & 0.2 & 0.5 & 1.1 \\
\hline
\end{tabular}

were separated by $6 \mathrm{ml} 0.25 \mathrm{M} \mathrm{HCl}$ and $2 \mathrm{ml} 0.75 \mathrm{M} \mathrm{HCl}$, respectively, using Eichrom Ln resin. Samples were taken up in a $1 \mathrm{ml}$ mixture of $2 \% \mathrm{HNO}_{3}$ and $0.1 \% \mathrm{HF}$. The $\mathrm{Sr}$ and $\mathrm{Nd}$ isotope ratios were analyzed using the Neptune MC:ICP MS in a static mode with 30 integration blocks (with 2 min duration for $\mathrm{Sr}$ and $\mathrm{Sm}$ isotopes and $4 \mathrm{~min}$ for $\mathrm{Nd}$ isotopes) followed by 8 min of washout. The cup configuration was the same as for LA MC ICP MS analysis. The aliquots were aspired using a dual glass spray chamber (wet plasma). Procedural blanks were $<150 \mathrm{pg}$ for $\mathrm{Sm}$ and $\mathrm{Nd}$ and $<300 \mathrm{pg}$ for $\mathrm{Sr}$ and thus negligible. During $\mathrm{Nd}$ isotope analysis, two measurements of Merck standard solution (500 ppb $\mathrm{Nd}_{2} \mathrm{O}_{3}$ ) yielded ${ }^{143} \mathrm{Nd} /{ }^{144} \mathrm{Nd}=0.511722 \pm 2$, which is very close to the suggested value by Deckart et al. (2005) and Caro et al. (2006). For the Sr isotopes, three measurements of NBS987 standard solution yielded ${ }^{87} \mathrm{Sr} /{ }^{86} \mathrm{Sr}=0.710260 \pm 17$, which is in agreement with literature values (e.g. Thirlwall 1991).

\section{$\mathrm{U}-\mathrm{Th}-\mathrm{Pb}$ geochronolgy}

In situ $\mathrm{U}-\mathrm{Th}-\mathrm{Pb}$ isotope analyses were carried out on perovskites from the Badberg soevite and from bergalites, on pyrochlores from the Schelingen soevite and on calzirtites and zirconolites from alvikites. Analyses were performed with a Thermo Finnigan Element 2 ICP MS connected with a Resonetics laser ablation system. Data were collected in time resolved-peak jumping-pulse counting mode over 810 mass scans with $19 \mathrm{~s}$ of background scanning followed by $30 \mathrm{~s}$ of sample ablation. Depending on the size of the grain and $\mathrm{U}$ content, the ablation spot varied from 30 to $65 \mu \mathrm{m}$. Off-line data processing was performed for correcting background signals, common $\mathrm{Pb}$, interferences of ${ }^{204} \mathrm{Hg}$, elemental fractionation during ablation and instrumental mass discrimination, using an $\operatorname{Excel}^{\odot}$ spreadsheet by Gerdes and Zeh $(2006,2009)$. For the correction of mass discrimination and elemental fractionation during ablation, we normalized the data to zircon GJ-1 (Jackson et al. 2004), which was repeatedly measured during each analytical sequence. As secondary standards and for quality control of the analysis we used zircon 91,500 (Wiedenbeck et al. 1995) and Ice River perovskite (Heaman 2009); the latter was particularly used for monitoring matrix effects observed in perovskite. The concordia and weighted average age diagrams were plotted, using Isoplot 4.

\section{Results}

\section{Mineral major and trace element compositions}

Minerals are partly oscillatory zoned and vary in composition from grain to grain. Selected analyses for major and trace elements of the perovskites, pyrochlores, zirconolites, calzirtites and garnets are given in Table 2 . Totals are always lower than $100 \%$ when $\mathrm{Fe}$ is calculated as $\mathrm{FeO}$. However, when all $\mathrm{Fe}$ is calculated as $\mathrm{Fe}_{2} \mathrm{O}_{3}$ and trace elements are recalculated to oxides, the totals always reach more than $99 \mathrm{wt} \%$. A confirmation for the existence of $\mathrm{Fe}^{3+}$ in such accessories is the report of $\mathrm{Fe}_{2} \mathrm{O}_{3}$ analysed directly in zirconolites (see review by Williams and Gieré, 1996). Also, high $\mathrm{Fe}_{2} \mathrm{O}_{3}$ in the accessories of Kaiserstuhl carbonatites is not surprising considering the high oxgygen fugacity (above the FMQ buffer) calculated by Braunger et al. (2018) for the Kaiserstuhl carbonatites. The range of trace element variations shown in Fig. 3 depicts the minimum and maximum values for each mineral species. Zirconolites and calzirtites have the overall highest trace element contents followed by pyrochlores, perovskites and melanites (Fig. 3). Calzirtites show fairly flat chondrite normalized REE patterns whereas they are negatively inclined for all other phases except for La that is lowered in pyrochlore, zirconolite and melanite. Perovskites Per01 and 03 (Table 2) are from the soevites. They have the highest $\mathrm{Nb}_{2} \mathrm{O}_{5}, \mathrm{Ta}_{2} \mathrm{O}_{5}$ and $\mathrm{Fe}_{2} \mathrm{O}_{3}$ of all three rock types. These elements are incorporated via the substitutions $\mathrm{Ca}+\mathrm{Ti} \leftrightarrow \mathrm{Na}+\mathrm{Nb}$ and $\mathrm{Ti}+\mathrm{Ti} \leftrightarrow \mathrm{Nb}+\mathrm{Fe}^{3+}$. Trace elements in other soevitic perovskites overlap with those in the alvikites. They are, therefore, combined in Fig. 3 within one compositional range. The perovskites from bergalites lie within this range for soevitic perovskites, esp. also the REE (Fig. 3c). 

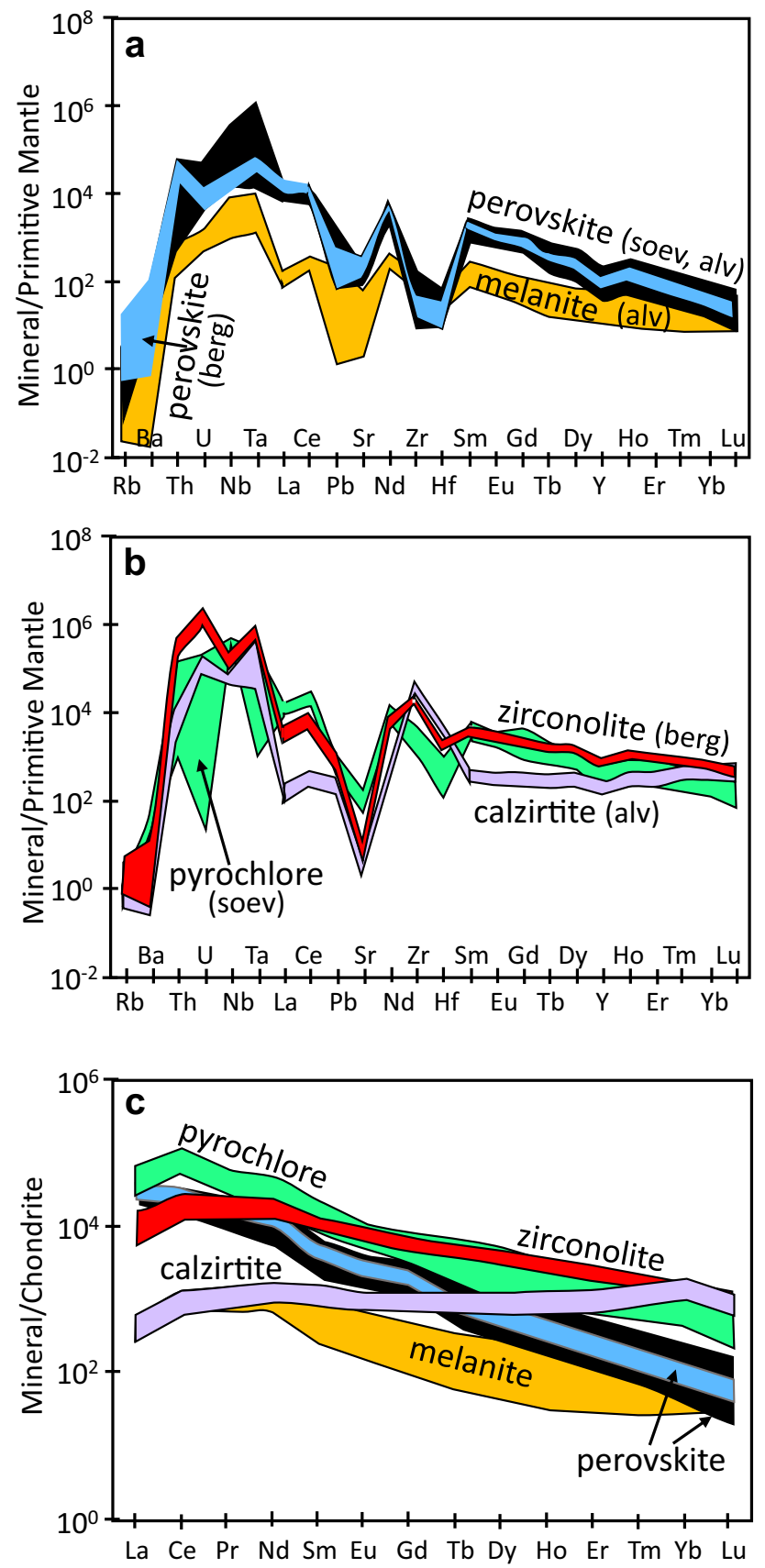

Fig. 3 a Primitive mantle normalized (McDonough and Sun 1995) spidergrams of perovskites from soevites (soev) + alvikites (alv), bergalites (berg) and melanite; b spidergrams of zirconolites, calzirtites and pyrochlores; $\mathbf{c}$ REE patterns of all phases normalized to chondrite (McDonough and Sun 1995)

\section{Mineral isotope compositions}

The results of single-spot measurements of isotope ratios are presented in Fig. 4 a-c, their average values with $2 \sigma$ deviations are given in Table 3. Figure 4 a shows the results for ${ }^{87} \mathrm{Sr} /{ }^{86} \mathrm{Sr}$ and $\mathrm{Sr}$ contents in perovskites and pyrochlores from bergalites, soevites and alvikites. Because of the very low
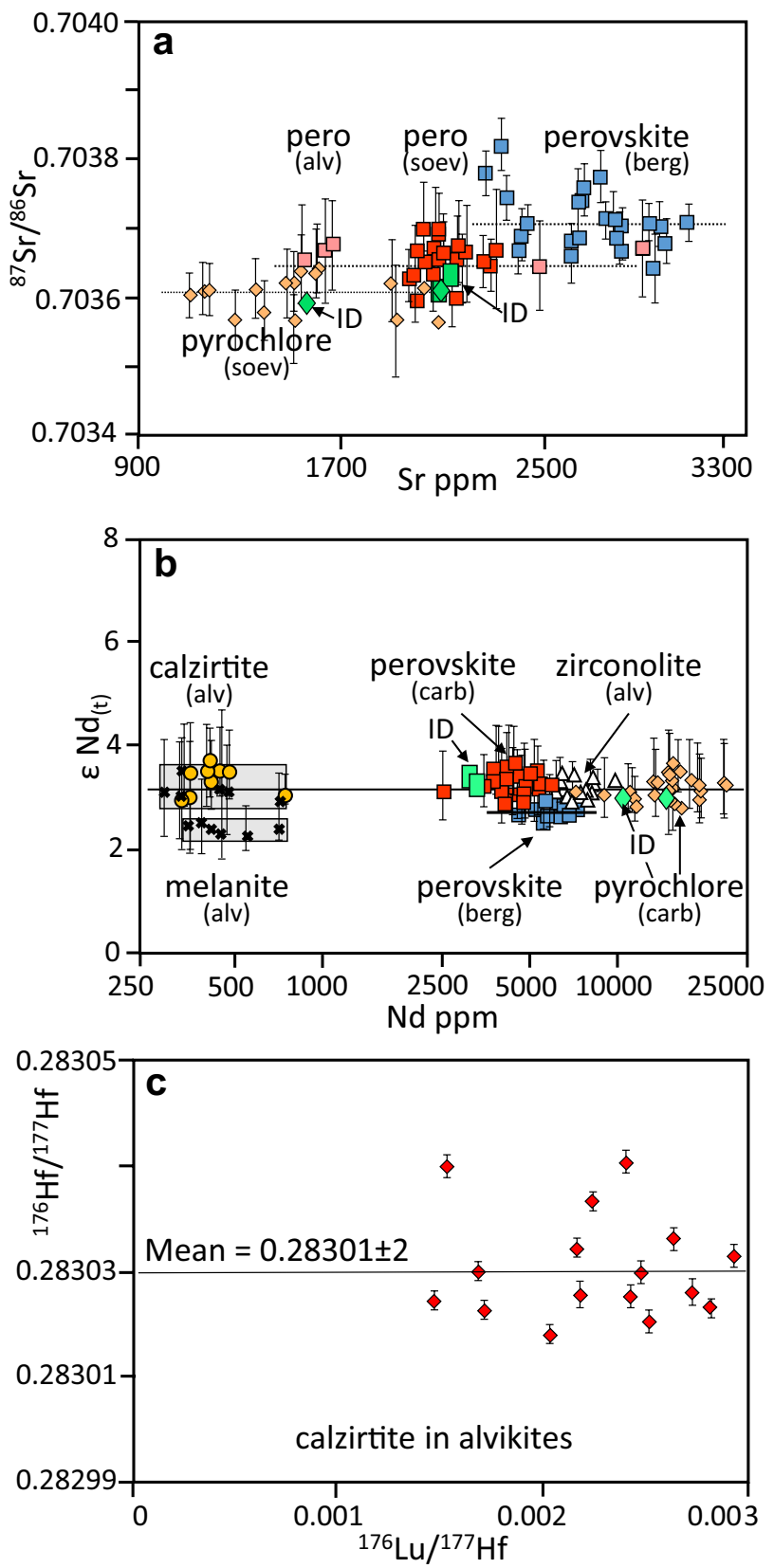

Fig. 4 a Single point measurements of ${ }^{87} \mathrm{Sr} /{ }^{86} \mathrm{Sr}$ and $\mathrm{Sr}$ contents in pyrochlores and perovskites (pero), black lines mark their averages. Green symbols are the values of ID measurements of pyrochlores respectively perovskites. $\mathbf{b} \varepsilon \mathrm{Nd}_{(\mathrm{t})}$ vs. $\mathrm{Nd}$ contents in ppm; the finer black line marks the average of all measurements except for those of perovskites from bergalites (average $=$ thicker black line) and of one of the two groups of melanite (black frame). ${ }^{176} \mathrm{Hf}^{177} \mathrm{Hf}_{(\mathrm{t})}$ vs ${ }^{176} \mathrm{Lu} /{ }^{177} \mathrm{Hf}$ in calzirtites from alvikites

abundances of $\mathrm{Rb}$ in perovskites and pyrochlores (Table 1) the measured values correspond to the initial ${ }^{87} \mathrm{Sr} /{ }^{86} \mathrm{Sr}$ ratios. The Sr-concentrations of pyrochlores from the Schelingen carbonatite range from about $1000-1900 \mathrm{ppm}(n=13)$ and the ${ }^{87} \mathrm{Sr} /{ }^{86} \mathrm{Sr}$ ratios vary between 0.70359 and 0.70370 . 
Table 3 Sr-, Nd- and Hf isotope ratios-averaged results from LA MC ICP MS measurements

\begin{tabular}{|c|c|c|c|c|c|c|c|c|c|c|}
\hline Isotopes in rock types & $n$ & Perovskite & $n$ & Pyrochlore & $n$ & Zirconolite & $n$ & Calcirtite & $n$ & andradite \\
\hline \multicolumn{11}{|l|}{${ }^{87} \mathrm{Sr} /{ }^{86} \mathrm{Sr}$} \\
\hline Sövite & 16 & $0.70365 \pm 3$ & 20 & $0.70361 \pm 3$ & & - & & - & & \\
\hline Alvikite & 6 & $0.70365 \pm 3$ & & - & & - & & - & & \\
\hline Bergalite & 24 & $0.70371 \pm 4$ & & - & & - & & - & & \\
\hline \multicolumn{11}{|l|}{${ }^{143} \mathrm{Nd} /{ }^{144} \mathrm{Nd}$} \\
\hline $\begin{array}{l}\text { Sövite } \\
\varepsilon N d\end{array}$ & 7 & $\begin{array}{l}0.512780 \pm 1 \\
3.1 \pm 0.3\end{array}$ & & $\begin{array}{l}0.512773 \pm 2 \\
3.0 \pm 0.3\end{array}$ & 26 & & & & & \\
\hline $\begin{array}{l}\text { Alvikite } \\
\varepsilon N d\end{array}$ & 21 & $\begin{array}{l}0.512781 \pm 2 \\
3.2 \pm 0.3\end{array}$ & & - & 26 & $\begin{array}{l}0.512781 \pm 1 \\
3.2 \pm 0.2\end{array}$ & 17 & $\begin{array}{l}0.512777 \pm ? ? \\
3.3 \pm 0.3\end{array}$ & 13 & $\begin{array}{l}0.512759 \pm 2 \\
2.8 \pm 0.4\end{array}$ \\
\hline $\begin{array}{l}\text { Bergalite } \\
\varepsilon N d\end{array}$ & 36 & $\begin{array}{l}0.512764 \pm 1 \\
2.8 \pm 0.2\end{array}$ & & - & & & & - & & - \\
\hline $\begin{array}{l}{ }^{176} \mathrm{Hf} /{ }^{177} \mathrm{Hf} \\
\varepsilon \mathrm{Hf}(\mathrm{t})\end{array}$ & & - & & - & & - & 16 & $\begin{array}{l}0.28301 \pm 2 \\
8.3 \pm 2\end{array}$ & & - \\
\hline
\end{tabular}

The Sr-concentrations and ${ }^{87} \mathrm{Sr} /{ }^{86} \mathrm{Sr}$ ratios in perovskites from alvikites and the Badberg soevite completely overlap and range from 1500 to $2800 \mathrm{ppm}(n=19)$ and 0.70356 to 0.70366 . Perovskites in bergalites have $\mathrm{Sr}$-concentrations between 2200 and $3000 \mathrm{ppm}(n=23)$ and ${ }^{87} \mathrm{Sr} /{ }^{86} \mathrm{Sr}$ ratios of 0.70364-0.70382. The latter are highest both in concentration levels and isotope ratios of all measured mineral grains. The averaged ${ }^{87} \mathrm{Sr} /{ }^{86} \mathrm{Sr}$ ratios (Table 3) are lowest in the pyrochlores $(0.70361)$. They overlap within the error with the somewhat higher average $(0.70365)$ of the perovskites from alvikite and of the Badberg soevite from Badberg. The latter only marginally overlaps with the high average of 0.70371 of the perovskites from bergalites.

Element concentrations were high enough to determine the ${ }^{143} \mathrm{Nd} /{ }^{144} \mathrm{Nd}$ isotope ratios in all phases that were separated from bergalites, alvikites and soevites. The results of single measurements are shown in Fig. 4b) in a diagram of $\varepsilon \mathrm{Nd}_{(t)}$ versus $\mathrm{Nd}$ concentration and averaged values are given in Table 3. Neodymium concentrations are lowest in calzirtite and garnets (around 400 ppm), significantly higher in perovskites ( $5000 \mathrm{ppm})$ followed by zirconolite $(7000 \mathrm{ppm})$ and then pyrochlore $(15,000 \mathrm{ppm})$. The ${ }^{143} \mathrm{Nd} /{ }^{144} \mathrm{Nd}$ values are time corrected (15 Ma) and the corresponding $\varepsilon \mathrm{Nd}$ values calculated according to the chondritic value of ${ }^{143} \mathrm{Nd} /{ }^{144} \mathrm{Nd}=0.512638$ (Bouvier et al. 2008). In general, the ${ }^{143} \mathrm{Nd} /{ }^{144} \mathrm{Nd}$ values of all phases overlap closely within their $2 \sigma$ errors and give an average of 0.512774
( $n=83$ ). In detail, the values of one group of garnets lies below those of all other phases while a second group falls within their range. The garnet group with the lower values does not differ in texture or major element composition from the other garnet group. Also, the perovskites from the bergalites form a group on the low side of the $\mathrm{Nd}$ isotope range of all other phases.

The Lu-Hf isotopes could be analyzed only in calzirtites from alvikites. The results for 16 analyses are shown in Fig. 4c in a ${ }^{176} \mathrm{Hf} /{ }^{177} \mathrm{Hf}$ versus ${ }^{176} \mathrm{Lu} /{ }^{177} \mathrm{Hf}$ diagram. The average is $0.28301 \pm 2$ (Table 3 ) that corresponds to $\varepsilon \mathrm{Hf}(t)=+8.3$.

A larger number of individual analyses of an isotopically homogeneous material statistically yields an accurate average value with a low $2 \sigma$ error that corresponds to the value obtainable by isotope solution. Indeed, the duplicate isotope dilution measurements for the $\mathrm{Sr}$ and $\mathrm{Nd}$ isotope ratios of perovskites and pyrochlores correspond within the isotope dilution error to the average values from LA-ICP-MS measurements (Fig. 4a,b and Table 4).

\section{$\mathrm{U}-\mathrm{Th}-\mathrm{Pb}$ geochronology}

$\mathrm{U}-\mathrm{Pb}$ ages were determined for perovskites, pyrochlores, calzirtites and zirconolites from the soevites and alvikites. Error ellipses of all individual measurements are shown in concordia diagrams (Fig. 5a-d); derived U-Pb and
Table $4 \mathrm{Nd}$ and $\mathrm{Sr}$ isotope ratios - results from isotope dilution

\begin{tabular}{lllll}
\hline & Badberg Pero1 & Badberg Pero2 & Schelingen Pyro 1 & Schelingen Pyro 2 \\
\hline${ }^{143} \mathrm{Nd} /{ }^{144} \mathrm{Nd}$ & $0.512793 \pm 4$ & $0.512784 \pm 4$ & $0.512771 \pm 4$ & $0.512773 \pm 4$ \\
$\varepsilon \mathrm{Nd}$ & $3.4 \pm 0.08$ & $3.2 \pm 0.08$ & $3.0 \pm 0.09$ & $3.0 \pm 0.09$ \\
$\mathrm{Nd}$ conc ppm & 3321 & 3539 & 10,362 & 15,792 \\
${ }^{87} \mathrm{Sr} /{ }^{86} \mathrm{Sr}$ & $0.703608 \pm 18$ & $0.703634 \pm 18$ & $0.703611 \pm 12$ & $0.703586 \pm 15$ \\
$\mathrm{Sr}$ conc ppm & 2074 & 2038 & 2092 & 1367 \\
\hline
\end{tabular}


Fig. $5 \mathrm{U}-\mathrm{Th}-\mathrm{Pb}$ ages of a perovskites from Badberg soevites, b of pyrochlores in soevites from Schelingen, $\mathbf{c}$ of calzirtites in alvikites from Brettel and $\mathbf{d}$ of zirconolites in alvikites from Brettel. $\mathbf{e}+\mathbf{f}$ Weighted average ages of ${ }^{208} \mathrm{~Pb} /{ }^{232} \mathrm{Th}$ and ${ }^{206} \mathrm{~Pb} /{ }^{238} \mathrm{U}$ of perovskites from bergalites
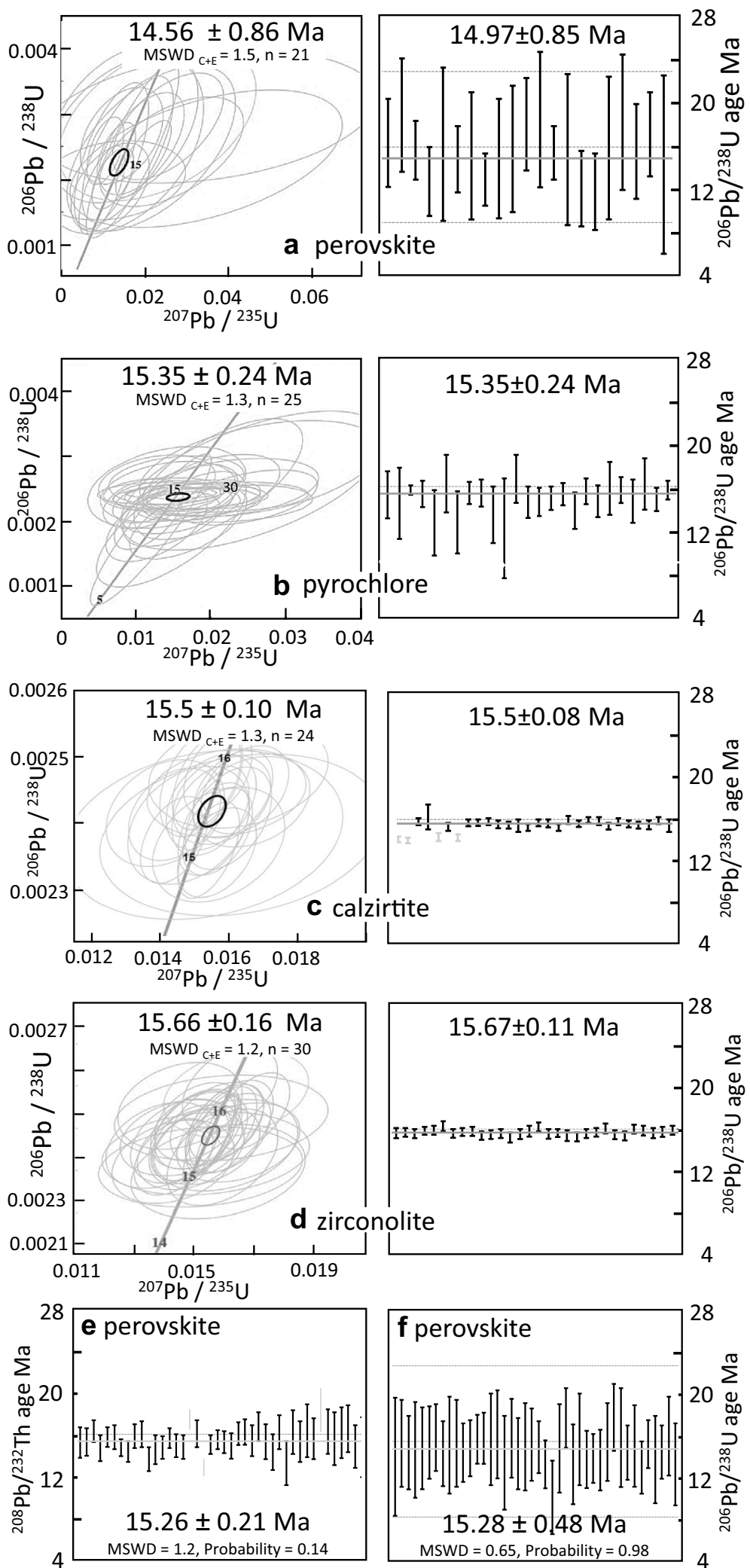

${ }^{206} \mathrm{~Pb} /{ }^{238} \mathrm{U}$ ages are given in the figures and in Table 5. A found for perovskites from the Badberg soevite. Pyrochlores from the Schelingen soevite gave a concordia age and also a ${ }^{206} \mathrm{~Pb} /{ }^{238} \mathrm{U}$ weighted average age of $15.35 \pm 0.24 \mathrm{Ma}$ 
Table $5 \mathrm{U}-\mathrm{Th}-\mathrm{Pb}$ isotope ratios from LA MC ICP MS measurements and derived ages

\begin{tabular}{|c|c|c|c|c|c|}
\hline Mineral & Perovskite & & Pyrochlore & Zirconolite & Calcirtite \\
\hline Rocktype $(n)$ & Sövite (21) & Bergalite (41) & Sövite (24) & Alvikite (28) & Alvikite (24) \\
\hline${ }^{206} \mathrm{~Pb} /{ }^{238} \mathrm{U}$ & $0.00235 \pm 27$ & $0.00239 \pm 20$ & $0.00233 \pm 16$ & $0.00243 \pm 4$ & $0.00241 \pm 4$ \\
\hline${ }^{207} \mathrm{~Pb} /{ }^{235} \mathrm{U}$ & $0.01670 \pm 636$ & $0.01196 \pm 222$ & $0.01638 \pm 383$ & $0.01536 \pm 67$ & $0.1547 \pm 7$ \\
\hline${ }^{208} \mathrm{~Pb} /{ }^{232} \mathrm{Th}$ & & $0.00076 \pm 5$ & & & \\
\hline \multicolumn{6}{|l|}{ Ages in $\mathrm{Ma}$} \\
\hline Concordia & $14.56 \pm 0.86$ & & $15.35 \pm 0.24$ & $15.6 \pm 0.1$ & $15.5 \pm 0.1$ \\
\hline${ }^{206} \mathrm{~Pb} /{ }^{238} \mathrm{U}$ & $14.97 \pm 0.85$ & $15.28 \pm 0.48$ & $15.35 \pm 0.24$ & $15.5 \pm 0.01$ & $15.5 \pm 0.08$ \\
\hline${ }^{208} \mathrm{~Pb} /{ }^{232} \mathrm{Th}$ & & $15.26 \pm 0.21$ & & & \\
\hline
\end{tabular}

(Fig. 5b). The Zr-rich minerals calzirtite and zirconolite from alvikites give similar concordia ages of $15.5( \pm 0.1)$ and $15.66 \pm 0.16 \mathrm{Ma}$ and ${ }^{206} \mathrm{~Pb} /{ }^{238} \mathrm{U}$ ages of $15.5( \pm 0.08)$ respectively $15.67 \pm 0.11 \mathrm{Ma}$ (Fig. $5 \mathrm{c}$, d and Table 5). Perovskites from the bergalites did not yield a concordia age because of their low $U$ and high common lead abundances. They only gave a lower but not an upper intercept value. Instead, their ${ }^{206} \mathrm{~Pb} /{ }^{238} \mathrm{U}$ and ${ }^{208} \mathrm{~Pb} /{ }^{232} \mathrm{Th}$ yielded averaged ages of $15.28 \pm 0.48 \mathrm{Ma}$ and $15.26 \pm 0.21 \mathrm{Ma}$, respectively (Fig. 5e, f and Table 5). Calzirtite, zirconolite, pyrochlore and perovskites from bergalites give the same ages within error around 15.45 Ma whereas the perovskites from soevite give a younger age of $14.56 \mathrm{Ma}$. This age with a large $2 \sigma$ error barely overlaps with that of the other phases. Pyrochlores from soevite give an older age consistent with that from the other accessories.

Analogous to the various isotope ratios, the average of a larger number of $\mathrm{U}-\mathrm{Pb}$ analyses statistically gives a very good precision and accuracy of the in-situ age values. A precision of around $\pm 0.2 \mathrm{Ma}$ is significantly better than the $\pm 0.7 \mathrm{Ma}$ of the previous methods employed in the Kaiserstuhl. The exception is the age of $14.56 \mathrm{Ma}$ with its large error of $\pm 0.86 \mathrm{Ma}$ for the perovskites from the Badberg. This large error could be due to the relatively low $\mathrm{U}$ and $\mathrm{Pb}$ abundances in these perovskites compared to zirconolite, pyrochlore and calzirtite and the larger variability of the trace elements compared to the pervoskites from the bergalites (Fig. 3).

\section{Discussion}

\section{Accessories as accurate and reliable age monitors of their whole rocks}

Existing age data for the Kaiserstuhl tephrites, essexites and phonolites are shown in Fig. 6 together with our new data on the accessories from the carbonatites and bergalites. The former fall in the time span between 16.2 and $17.8 \mathrm{Ma}$ and mark the main intrusive and extrusive activity in the

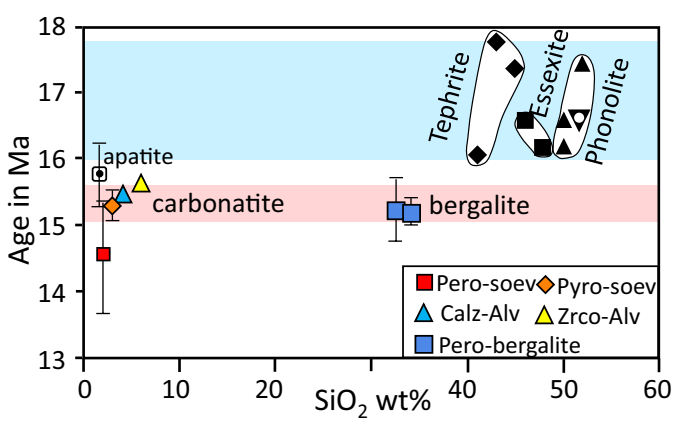

Fig. $6 \mathrm{~K}-\mathrm{Ar}$ ages (Ma) of tephrites, essexites and phonolites (black filled symbols) as determined by Lippolt et al. (1963) plotted against $\mathrm{SiO}_{2}$ taken from Wimmenauer (2003). Errors for the $\mathrm{K}-\mathrm{Ar}$ ages are around $\pm 0.7 \mathrm{Ma}(2 \sigma)$. The black, up-side down triangle with the white dot is the average of four ages obtained by Kraml et al. (2006) from minerals of the phonolitic Limberg T3 tephra: apatite by fission track, apatite and titanite each by $(\mathrm{U}-\mathrm{Th}) / \mathrm{He})$ and sanidine by laser Ar-Ar. Coloured symbols are the results from the present study.)

Kaiserstuhl. Age data for the carbonatites and related rocks were not available before our study except for one younger apatite fission track age of $15.8 \pm 0.5$ from a carbonatite (Wagner 1976).

We obtained significantly younger ages for the carbonatites and bergalites. Perovskites from the Badberg gave the youngest age of 14.56 Ma but with a large error. Still, the age overlaps within error with the more precise ages of the other phases (Fig. 6). These span the time range between 15.35 and $15.67 \mathrm{Ma}$ (Table 5 and Fig. 6) including the ${ }^{208} \mathrm{~Pb} /{ }^{232} \mathrm{Th}$ and ${ }^{206} \mathrm{~Pb} /{ }^{238} \mathrm{U}$ ages of the perovskites from the bergalites. The bergalite dykes intrude the carbonatites and are thus geologically younger. However, this is not resolvable with our methods. Pyrochlores, calzirtites and zirconolites yield the most precise age data with errors of only 0.1-0.2 Ma. Perovskite ages are less precise because of their relatively lower $\mathrm{U}$ and lead contents.

The $\mathrm{K}-\mathrm{Ar}$ and Ar-Ar age data for the Kaiserstuhl from the literature entirely stem from the geologically older extrusive tephrites and intrusive phonolites and essexites while our in-situ age determinations are from members of the 
geologically younger carbonatite and carbonate-rich foidite family (Fig. 1b). These two rock groups have been distinguished based on field relationships, mineralogy, petrology and geochemistry. Their difference in time can now be quantified by geochronology. The ages of the main Kaiserstuhl rock types lie between 16.2 and $17.8 \mathrm{Ma}$, i.e. they signal a long time span for emplacement of 1.6 Ma. The new ages from the accessory phases are significantly younger between 15.35 and 15.67 Ma and demonstrate that the carbonatites and foidites intruded within a much shorter time span of $0.32 \mathrm{Ma}$. The phase of intrusion of the carbonatitic rocks is much shorter than the main build-up of the volcanic edifice.

\section{Accessories as accurate fingerprints of the isotopic composition of their host rocks}

Based on the $\mathrm{Sr}, \mathrm{Nd}$ and $\mathrm{Pb}$ isotope characteristics Schleicher et al. (1990 a,b) distinguished three groups of volcanics and subvolcanics in the Kaiserstuhl (see above "General Geology"). The $\mathrm{Sr}$ and $\mathrm{Nd}$ isotope fields are outlined in Fig. 7a, b). Olivine nephelinites and melilitites (from the Kaiserstuhl and its surroundings) have the lowest ${ }^{87} \mathrm{Sr} /{ }^{86} \mathrm{Sr}$ and the most positive ${ }^{143} \mathrm{Nd} /{ }^{144} \mathrm{Nd}$ ratios. Their major and trace elements closely correspond to primary melt compositions. Tephrites, essexites and phonolites have the highest ${ }^{87} \mathrm{Sr} /{ }^{86} \mathrm{Sr}$ and lower ${ }^{143} \mathrm{Nd} /{ }^{144} \mathrm{Nd}$ ratios than the primary melts and represent fractionated alkaline rocks. Carbonatites, bergalites and hauynophyres have ${ }^{87} \mathrm{Sr} /{ }^{86} \mathrm{Sr}$ ratios overlapping with those of the primary magmas and ${ }^{143} \mathrm{Nd} /{ }^{144} \mathrm{Nd}$ ratios intermediate between but also overlapping on either end with the primary melts and the fractionated alkaline rocks. Primary melts and the carbonatitic to foiditic rocks plot within the mantle array in a ${ }^{143} \mathrm{Nd} /{ }^{144} \mathrm{Nd} \mathrm{vs}{ }^{87} \mathrm{Sr} /{ }^{86} \mathrm{Sr}$ diagram (Fig. $7 b$ ) whereas the fractionated alkaline rocks align oblique to the mantle array and lie partly outside.

Our new isotope data on accessories in carbonatites and bergalites are in accord with this division. They appear, however, to be more precise and accurate and allow finer distinctions than whole rock data. This is especially apparent for the ${ }^{87} \mathrm{Sr} /{ }^{86} \mathrm{Sr}$ ratios. The new mineral ${ }^{87} \mathrm{Sr} /{ }^{86} \mathrm{Sr}$ values overlap with the values of the primary magma field and fully overlap with the carbonatite whole rocks (Fig. 7a). The field for the bergalites, however, lies at somewhat higher ${ }^{87} \mathrm{Sr} /{ }^{86} \mathrm{Sr}$ ratios than the values for the perovskites from bergalites and the carbonatite field. This may reflect a meteoric influence in the easily weathering bergalites as suggested by Hubberten et al. (1988) on the basis of whole rock oxygen isotopes. Combined with the $\mathrm{Nd}$-isotope ratios the field for carbonatite and bergalite accessories falls somewhat removed from the previously established carbonatite-bergalite field onto the edge of the mantle array (Fig. $7 \mathrm{~b}$ ), Both the $\mathrm{Sr}$ and $\mathrm{Nd}$ isotope ratios are lower possibly also reflecting a meteoric influence in
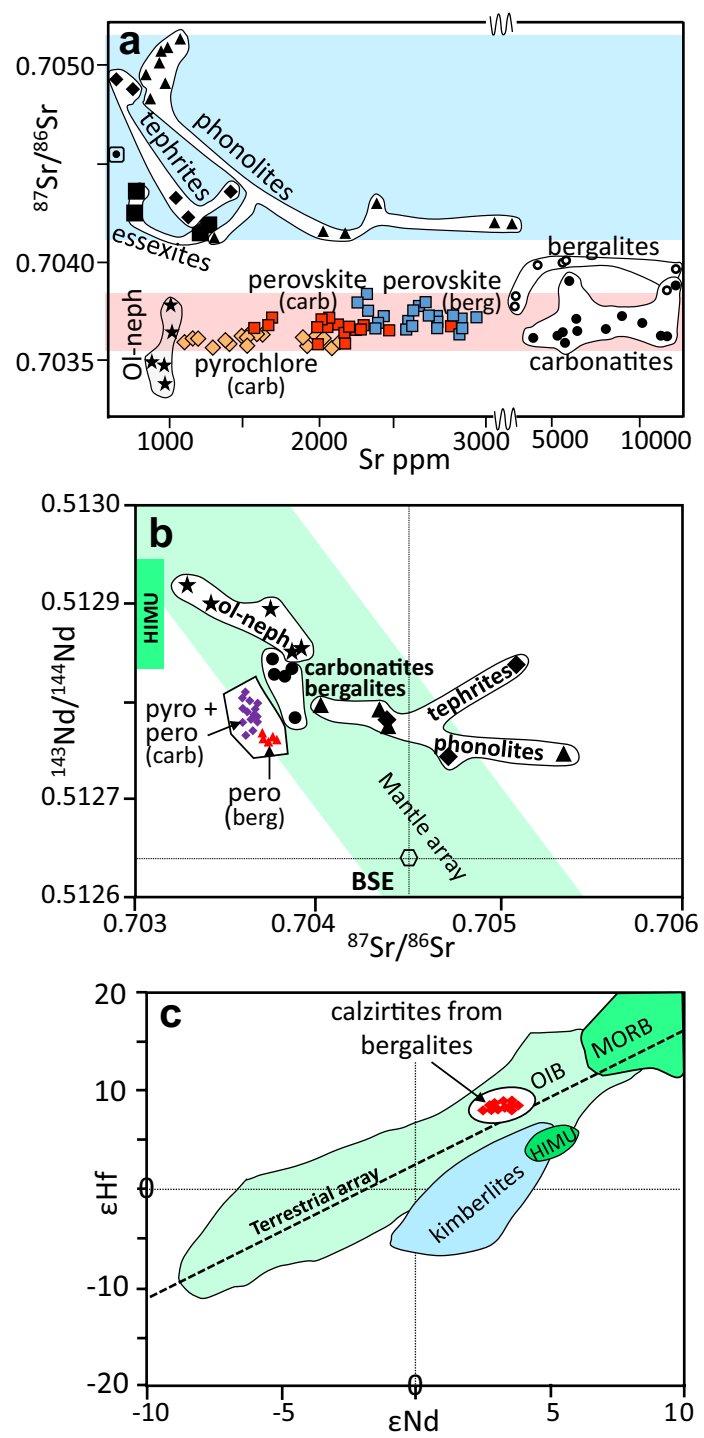

Fig. 7 The outlined fields with black symbols depict the range of whole rock data after Schleicher et al. (1990) The colored symbols are our own new data. a Comparison of the ${ }^{87} \mathrm{Sr} /{ }^{86} \mathrm{Sr}$ ratios and $\mathrm{Sr}$ contents of whole rock and minerals. b Comparison of the ${ }^{143} \mathrm{Nd} /{ }^{144} \mathrm{Nd}$ and ${ }^{87} \mathrm{Sr} /{ }^{86} \mathrm{Sr}$ isotope ratios of whole rocks and and pyrochlores and perovskites from carbonatites and bergalites. Also shown are the mantle array and the right-hand edge of the HIMU field. $\mathbf{c} \varepsilon \mathrm{Hf}$ vs $\varepsilon N d$ for calzirtites from bergalites. They plot within the field of oceanic island basalts just above the terrestrial array. Fields of MORB and OIB are from Dobosi et al. (2003) and Vervoort and BlichertToft (1999). The Terrestrial Array is from Vervoort and Blichert-Toft (1999)

the whole rocks. Furthermore, the perovskites from bergalites plot somewhat away from the pyrochlores and perovskites from carbonatites to even lower Nd values. The Hf-isotopes could only be determined in calzirtites from the bergalites. Combined with their Nd-isotopes they plot in an $\varepsilon \mathrm{Hf}$ versus $\varepsilon \mathrm{Nd}$ diagram within the field of oceanic 
island basalts above the terrestrial array in the quadrant for long time depletion (Fig. 7c).

\section{Genetic relationships amongst the Kaiserstuhl magmatic rocks}

The intrusion and extrusion of the Kaiserstuhl magmatic rocks coincided with the updoming of the Moho underneath the Kaiserstuhl to $24 \mathrm{~km}$ depth, i.e. hot mantle material was rising underneath the Kaiserstuhl. This occurred during the uplift and N-S compression of the southern Rhine Graben segment in the late Aquitan and Burdigal (21-16 Ma; see overview by Keller et al. (2002), Lutz and Cleintuar (1999), Larroque and Laurent (1988). Schleicher et al. $(1990,1991)$ deduced the genetic relationships of the various intrusives and extrusives from the $\mathrm{Sr}-$, $\mathrm{Nd}-$ and $\mathrm{Pb}$ isotopic compositions and embedded them into a history of updoming of the mantle underneath the Kaiserstuhl: (a) they proposed that parental, primary olivine nephelinites stem from the upwelling of a long-time depleted mantle that was reenriched in incompatible elements in the cause of the rifting processes and that the derivative tephrites, essexites and phonolites are the products of AFC processes in the crust. (b) They also suggested that the carbonatites and bergalites stem from a second depleted mantle source whose isotopic composition was continuously, even though little modified by metasomatism in the process of the continued updoming of the asthenosphere. The carbonatites, bergalites and related magmas are not primary mantle melts but are differentiation products of olivine nephelinite magmas at high pressures. Prove for high-pressure crystal fractionation in the mantle is the presence of clinopyroxene megacrysts in olivine nephelinite tuffs in the Kaiserstuhl (Keller 1978; Ulianov et al. 2007). Keller (1978) demonstrated experimentally that these clinopyroxenes are high-pressure liquidus phases of the olivine nephelinites at around $2 \mathrm{GPa}$. The crystallisation of mainly clinopyroxene drives the residual liquids towards bergalitic and eventually carbonatitic melts. Whole rock REE patterns from olivine nephelinites to bergalites and carbonatites from Braunger et al. (2018) and Keller et al. (1990) are in qualitative agreement with such a model.

Similarly, Braunger et al. (2018) postulated two mantle sources with distinct prevailing oxygen fugacities. In their model, basanitic lamprophyres (monchiquites) are the primitive rocks for the tephrite to phonolite series with fractional crystallization of mainly clinopyroxene, amphibole and olivine accompanied by an increase in oxygen fugacity. Olivine melilititic magmas are the primary magmas for the bergalites (hauyne melilitites) and more fractionated rocks. These differentiates developed by fractional crystallization of mainly olivine, spinel/magnetite, melilite, perovskite and nepheline at even higher oxygen fugacities.
The model of Schleicher et al. (1990) contains the geological findings that the carbonatite-foidite group is younger than the tephrite-phonolite group. We have shown here that the time difference is considerable and almost one million years and that the time span for the emplacement of the tephrite-phonolite group is much longer than for the carbonatite-foidite group. Reasons for these differences may lie in processes connected with the updoming of the mantle underneath the Kaiserstuhl and in the differences of the properties of silicate and carbonatite melts. For the generation of the strongly Si-undersaturated primary melts the depth of partial melting and melt segregation is roughly constant in the mantle but the portion of the melting peridotite is renewed in an upwelling mantle with time. Because of the relative properties of small melt fractions of silicic or carbonatitic melts as metasomatizing agents Green (2015) hypothesized that a carbonate-bearing melt moves slower than a silicate melts and also slower than an upwelling mantle. If so and if partial melting is intermittent, an earlier melting process may tap a long-time depleted mantle portion (required by positive $\varepsilon \mathrm{Nd}$ ) that was refertilized in incompatible elements by a relatively water-rich, $\mathrm{CO}_{2}$-poor melt. The generated parental melts will differentiate into tephritic to phonolitic compositions. The second melting would occur in a depleted mantle that was metasomatised by a more carbonatitic melt. The resulting parental melts with higher $\mathrm{CO}_{2} /\left(\mathrm{CO}_{2}+\mathrm{H}_{2} \mathrm{O}\right)$ reach their volatile-saturated liquidus at higher pressures than those with lower $\mathrm{CO}_{2} /\left(\mathrm{CO}_{2}+\mathrm{H}_{2} \mathrm{O}\right)$ during uprise. They precipitate $\mathrm{Si}$-rich phases like clinopyroxene and differentiate eventually to foidites and carbonatites.

\section{Summary and conclusions}

We have shown that accessories from young carbonatites and carbonate-rich foidites are accurate and precise recorders of the age and isotopic compositions of their host rocks. Depending on the trace element abundances and patterns (mother/daughter element ratios) the investigated phases are variously suited for $\mathrm{U}-\mathrm{Pb}$ geochronology and the determination of their Sr-, Nd- and Hf-isotope ratios.

a) Zirconolite and calzirtite have highest $U$ contents and highest $\mathrm{U} / \mathrm{Pb}$ ratios. They yield the most precise ages with $2 \sigma$ errors of only $0.1 \mathrm{Ma}$ followed by pyrochlore with an error of $0.2 \mathrm{Ma}$. Errors of ${ }^{206} \mathrm{~Pb} /{ }^{238} \mathrm{U}$ ages are of similar size or less. Perovskites with lower $\mathrm{U} / \mathrm{Pb}$ ratios appear to be less suited because they either yield concordia ages with a much higher error or no age at all. Still, meaningful ages may be obtained from ${ }^{206} \mathrm{~Pb} /{ }^{238} \mathrm{U}$ and ${ }^{208} \mathrm{~Pb} /{ }^{232} \mathrm{Th}$ geochronology. 
b) Perovskites and pyrochlores have the highest Sr-contents. They yield ${ }^{87} \mathrm{Sr}^{86} \mathrm{Sr}$ ratios with a precision very close to that of isotope dilution measurements.

c) All accessory phases perovskite, pyrochlore, zirconolite, calzirtite and melanite are suitable for the precise determination of the Nd-isotopes.

d) The Hf-isotopes could only be determined with high precision in calzirtites. They have the largest positive $\mathrm{Zr}-\mathrm{Hf}$ anomalies compared to all other phases.

Zircon, baddeleyite zirconolite, calzirtite and perovskite have been previously used to determine precise $\mathrm{U}-\mathrm{Pb}$ ages and isotope ratios by SIMS and TIMS for various rock types from 130 - 2000 Ma old carbonatite complexes (Wu et al. 2010 and 2011; Heaman 2009). Our results show that this is also possible for a young volcanic complex like the Kaiserstuhl by LA ICPMS. They also confirm the findings of previous studies that precise data can be obtained from calzirtites and zirconolites (Wu et al. 2010) and perovskites and pyrochlores (Ghobadi et al. (2018).

Our new Sr-isotope ratios confirm the results of Schleicher et al. (1990) that olivine nephelinites and carbonatites with their associated carbonate-rich foidites entirely overlap which suggests a close genetic relationship between them. However, Schleicher et al. (1990) also pointed out that the olivine nephelinites had more negative $\varepsilon \mathrm{Nd}$ values and lower ${ }^{206} \mathrm{~Pb} /{ }^{204} \mathrm{~Pb}$ ratios. They resolved this by suggesting that the mantle source underneath the Kaiserstuhl was continuously modified by incoming melts or fluids during the updoming of the Moho. Indeed, our results show that at least $1 \mathrm{Ma}$ passed after the intrusion and extrusion of the main silicate rock types of the Kaiserstuhl until the carbonatites and bergalites were emplaced providing time for the modification of the carbonatite mantle source. This source has not directly produced the calcic carbonatites of the Kaiserstuhl as partial melts. Direct partial melting products of a carbonatized peridotitic mantle at low degrees are rather dolomitic (Wallace and Green 1988) that cannot reach the Earth's surface because of decarbonatization reactions on the way up.

Acknowledgements We thank Linda Marko for help in the clean lab and with mass spectrometry. We thank the Johann Wolfgang Goethe-Universität for making funds available to finance this project. FIERCE is financially supported by the Wilhelm and Else Heraeus Foundation and the Deutsche Forschungsgemeinschaft, which is gratefully acknowledged. This is FIERCE contribution no. 85. Detailed reviews by Ralf Halama and Michael Marks improved the manuscript significantly.

Funding Open Access funding enabled and organized by Projekt DEAL. The research was financially supported by the Johann Wolfgang Goethe-Universät Frankfurt.

\section{Declarations}

Conflict of interest Not applicable.

Availability of data and material All own data and material.

Code availability Not applicable.

Ethics approval Approved.

Consent to participate Not applicable.

Consent for publication Not applicable.

Open Access This article is licensed under a Creative Commons Attribution 4.0 International License, which permits use, sharing, adaptation, distribution and reproduction in any medium or format, as long as you give appropriate credit to the original author(s) and the source, provide a link to the Creative Commons licence, and indicate if changes were made. The images or other third party material in this article are included in the article's Creative Commons licence, unless indicated otherwise in a credit line to the material. If material is not included in the article's Creative Commons licence and your intended use is not permitted by statutory regulation or exceeds the permitted use, you will need to obtain permission directly from the copyright holder. To view a copy of this licence, visit http://creativecommons.org/licenses/by/4.0/.

\section{References}

Baranyi I, Lippolt H, Todt W (1976) Kalium-Argon Altersbestimmungen an tertiären Vulkaniten des Oberrheingraben-Gebietes II Der Alterstraverse Vom Hegau Nach Lothringen. Oberrhein Geol Abh 25:41-62

Bell (1998) Radiogenic isotope constraints on relationships between carbonatites and associated silicate rocks-a brief review. J Pet 39(11-12):1987-1996

Bell K, Kjarsgaard BA, Simonetti A (1999) Carbonatites-into the twenty-first century. J Petrol 39(11-12):1839-1845

Bouvier A, Vervoort JD, Patchett PJ (2008) The Lu: Hf and Sm: Nd isotopic composition of CHUR: Constraints from unequilibrated chondrites and implications for the bulk composition of terrestrial planets. Earth Planet Sci Lett 273:48-57

Braunger S, Marks MAW, Walter BF, Neubauer R, Reich R, Wenzel T, Parsapoor A, Markl G (2018) The petrology of the Kaiserstuhl Volcanic Complex, SW Germany: the importance of metasomatized and oxidized lithospheric mantle for carbonatite generation. J Petrol 59(9):1731-1762

Caro G, Bourdon B, Birck JL, Moorbath S (2006) High-precision ${ }^{142} \mathrm{Nd} /{ }^{144} \mathrm{Nd}$ measurements in terrestrial rocks: Constraints on the early differentiation of the Earth's mantle. Geochim Cosmochim Ac 70(1):164-191

Deckart K, Bertrand H, Liegeois JP (2005) Geochemistry and Sr, Nd, $\mathrm{Pb}$ isotopic composition of the Central Atlantic Magmatic Province (CAMP) in Guyana and Guinea. Lithos 82:289-314

Dobosi G, Kempton PD, Downes H, Embey-Isztin A, Thirlwall M, Greenwood P (2003) Lower crustal granulite xenoliths from the Pannonian Basin, Hungary, Part 2: $\mathrm{Sr}-\mathrm{Nd}-\mathrm{Pb}-\mathrm{Hf}$ and $\mathrm{O}$ isotope evidence for formation of continental lower crust by tectonic emplacement of oceanic crust. Contrib Mineral Pet 144:671-683 
Foster G, Vance D (2006) In situ Nd isotopic analysis of geological materials by laser ablation MC-ICP-MS. J Anal Atom Spec 21(3):288-296

Gerdes A, Zeh A (2006) Combined U-Pb and Hf isotope LA MC ICP MS analyses of detrital zircons: comparison with SHRIMP and new constraints for the provenance and!age of an Armorican metasediment in Central Germany. Earth Planet Sci Lett 249(12):47-61

Gerdes A, Zeh A (2009) Zircon formation versus zircon alterationnew insights from combined $\mathrm{U}-\mathrm{Pb}$ and $\mathrm{Lu}-\mathrm{Hf}$ in-situ LA-ICPMS analyses, and consequences for the interpretation of Archean zircon from the Central Zone of the Limpopo Belt. Chem Geol 261(3-4):230-243

Ghobadi M, Gerdes A, Kogarko L, Hoefer H, Brey GP (2018) In situ LA-ICPMS isotopic and geochronological studies on carbonatites and phoscorites from the Guli Massif, Maymecha-Kotuy, Polar Siberia. Geochem Int 56(8):766-783

Gittins J, Harmer RE (2003) Myth and reality in the carbonatite-silicate rock "association" Per. Mineral 72:19-26

Green DH (2015) Experimental petrology of peridotites, including effects of water and carbon on melting in the Earth's upper mantle. Phys Chem Miner 42:95-122

Griffin WL, Powell WJ, Pearson NJ, O'Reilly SY (2008) GLITTER: data reduction software for laser ablation ICP MS. Laser Ablation (ICP(MS) in the Earth Sciences, vol 40, pp 204-207

Heaman LM (2009) The application of U-Pb geochronology to mafic, ultramafic and alkaline rocks: An evaluation of three mineral standards. Chem Geol 261(1-2):43-52

Hubberten H-W, Katz-Lehnert K, Keller J (1988) Carbon and oxygen isotopic investigations in carbonatites and related rocks from the Kaiserstuhl, Germany. Chem Geol 70:257-274

Jackson S, Pearson N, Griffin W, Belousova E (2004) The application of laser ablation-inductively coupled plasma-mass spectrometry to in situ U-Pb zircon geochronology. Chem Geol 211:47-69

Jones AP, Genge M, Carmody L (2013) Carbonate melts and carbonatites. Rev Mineral Geochem 75(1):289-322

Katz K, Keller J (1981) Comb-layering in carbonatite dykes. Nature 294:350-352

Keller J (1981) Carbonatitic volcanism in the Kaiserstuhl alkaline complex: evidence for highly fluid carbonatitic melts at the Earth's surface. J Volcanol Geoth Res 9(4):423-431

Keller J (1984a) Geochemie und Magmenentwicklung im Kaiserstuhl. Fort Mineral 62(1):116-118

Keller J (1984b) Der jungtertiäre Vulkanismus Südwestdeutschlands: Exkursionen im Kaiserstuhl und Hegau Fortschritte Der Mineralogie. Beiheft 62(2):2-35

Keller J (1989) Extrusive carbonatites and their significance. In: Bell K (ed) Carbonatites-genesis and evolution. Unwin Hyman, London, pp 70-88

Keller J, Brey G, Lorenz V, Sachs P (1990) Volcanism and petrology of the Upper Rhinegraben (Urach-Hegau-Kaiserstuhl). In: IAVCEI Int Volc Congress Mainz 1990. Field Guide, p 60

Keller J, Kraml M, Henjes-Kunst F (2002) ${ }^{40} \mathrm{Ar} /{ }^{39} \mathrm{Ar}$ single crystal laser dating of early volcanism in the Upper Rhine Graben and tectonic implications. Schweiz Mineral Petrogr Mitt 82:121-130

Keller J (1978) Megakristalle von Al-reichem Klinopyroxen in Olivinnepheliniten und deren experimentelle Modellierung als Hochdruck-Liquidusphasen.-Fortschr Mineral 56, Beih.1: 56-57

Kogarko LN, Lahaye Y, Brey GP (2009) Plume-related mantle source of super-large rare metal deposits from the Lovozero and Khibina massifs on the Kola Peninsula, Eastern part of Baltic Shield: Sr, Nd and Hf isotope systematics. Mineral Pet 98(1-4):197-208

Kraml M, Pik R, Rahn M, Selbekk R, Carignan J, Keller J (2006) A new multi-mineral age reference material for ${ }^{40} \mathrm{Ar} /{ }^{39} \mathrm{Ar}$, (U-Th)/ $\mathrm{He}$ and fission track dating methods: the Limberg T3 Tuff. Geost Geoanal Res 30(2):73-86
Larroque JM, Laurent P (1988) Evolution of the stressfield in the south of the Rhinegraben from Eocene to present. Tectonophysics 148:41-58

Lehnert K (1989) Petrologie der Gangkarbonatite im Kaiserstuhl. Dissertation. Albert-Ludwigs-Universität, Freiburg

Lippolt HJ, Gentner W, Wimmenauer W (1963) Altersbestimmungen nach der Kalium-Argon-Methode an tertiären Eruptivgesteinen Südwestdeutschlands, Jahreshefte des Geologischen Landesamtes Baden-Württemberg" 6:507-538

Lutz M, Cleintuar M (1999) Geological results of a hydrocarbon exploration campaign in the southern Upper Rhine Graben. Bull Appl Geol 4:3-80

McDonough WF, Sun S-S (1995) The composition of the Earth. Chem Geol 120(3-4):223-253

Mitchell RH, Wu FY, Yang Y-H (2011) In situ U-Pb, Sr and Nd isotopic analysis of loparite by LA-(MC)-ICP-MS. Chem Geol 280(1-2):191-199

Patchett PJ, Tatsumoto M (1980) Hafnium isotope variations in oceanic basalts. Geophys Res Lett 7(12):1077-1080

Ramos FC, Wolff JA, Tollstrup DL (2004) Measuring ${ }^{87} \mathrm{Sr} /{ }^{86} \mathrm{Sr}$ variations in minerals and groundmass from basalts using LA-MCICPMS. Chem Geol 211(1-2):135-158

Rankenburg K, Lassiter JC, Brey GP (2004) Origin of megacrysts in volcanic rocks of the Cameroon volcanic chain-constraints on magma genesis and crustal contamination. Contrib Miner Pet 147(2):129-144

Rasmussen B, Fletcher IR (2004) Zirconolite: a new U-Pb chronometer for mafic igneous rocks. Geology 32:785-788

Schleicher H (1986) Isotopengeochemie der Alkalivulkanite des Kaiserstuhls (ein Beitrag zu ihrer Genese mit Hilfe radiogener Isotope). Habilitation. Thesis, University of Freiburg

Schleicher H, Keller J, Kramm U (1990) Isotope Studies on Alkaline Volcanics and Carbonatites from the Kaiserstuhl, Federal Republic of Germany. Lithos 26:21-35

Schleicher H, Baumann A, Keller J (1991) Pb isotopic systematics of alkaline volcanic rocks and carbonatites from the Kaiserstuhl, upper Rhine rift valley. FRG Chem Geol 93(3-4):231-243

Sylvester PJ (2008) Laser ablation ICP MS in the earth sciences: current practices and outstanding issues. Min Assess Canada Short Course Ser 40:356

Thirlwall MF (1991) Long term reproducibility of multicollector $\mathrm{Sr}$ and $\mathrm{Nd}$ isotope ratio analysis. Chem Geol Isot Geosci Sect 94(2):85-104

Ulianov A, Muntener O, Ulmer P, Pettke T (2007) Entrained Macrocryst Minerals as a Key to the Source Region of Olivine Nephelinites Limberg, Kaiserstuhl, Germany. J Pet 48(6):1079-1118

Vervoort JD, Blichert-Toft J (1999) Evolution of the depleted mantle: $\mathrm{Hf}$ isotope evidence from juvenile rocksthrough time. Geochim Cosmochim Acta 63(3):533-556

Vroon PZ, Van der Wagt B, Koornneef JM, Davies GR (2008) Problems in obtaining precise and accurate $\mathrm{Sr}$ isotope analysis from geological materials using laser ablation MC: ICPMS. Anal Bioanal Chem 390(2):465-476

Wagner G (1976) Spaltspurendatierungen an Apatit und Titanit aus den Subvulkaniten des Kaiserstuhls. Neues Jb Mineral, Monatsh 9:389-393

Wallace ME, Green DH (1988) An experimental determination of primary carbonatite magma composition. Nature 335:343-346

Wang LX, Marks MA, Wenzel T, Von der Handt A, Keller J, Teiber H, Markl G (2014) Apatites from the Kaiserstuhl Volcanic Complex, Germany: new constraints on the relationship between carbonatite and associated silicate rocks. Eur J Mineral 26(3):397-414

Wiedenbeck M, Alle P, Corfu F, Griffin WL, Meier M, Spiegel OFW (1995) Three natural zircon standards for U:Th:Pb, Lu:Hf, trace element and REE analyses. Geostand Newslett 19(1):1-23 
Williams and Gieré (1996) Zirconolite: A Review of Localities Worldwide, and a Compilation of its Chemical Compositions. Bulletin of the Natural History Museum London, 52 (1), 1-24. Retrieved from http://repository.upenn.edu/ees_papers/95

Wimmenauer W (1966) The eruptive rocks and carbonatites of the Kaiserstuhl Germany. In: Tuttle OF, Gittins J (eds) Carbonatites. Interscience, New York, pp 183-204

Wimmenauer W (2003) Geologische Karte von Baden-Württemberg, Erläuterungen zum Blatt Kaiserstuhl, 280 p., Landesamt für Geologie, Rohstoffe und Bergbau, Freiburg

Wu FY, Yang Y-H, Mitchell RH, Bellatreccia F, Li Q-L, Zhao Z-F (2010) In situ U-Pb and $\mathrm{Nd}-\mathrm{Hf}-(\mathrm{Sr})$ isotopic investigations of zirconolite and calzirtite. Chem Geol 277(1-2):178-195
Wu FY, Yang Y-H, Li Q-L, Mitchell RH, Dawson JB, Brandl G, Yuhara $\mathrm{M}$ (2011) In-situ determination of U-Pb ages and $\mathrm{Sr}-\mathrm{Nd}-\mathrm{Hf}$ isotopic constraints on the petrogenesis of the Phalaborwa carbonatite Complex, South Africa. Lithos 127(1-2):309-322. https:// doi.org/10.1016/j.lithos.2011.09.005

Yang Y-H, Wu FY, Yang J-H, Mitchell RH, Zhao Z-F, Xie L-W, Huang C, Ma Q, Yang M, Zhao H (2018) U-Pb age determination of schorlomite garnet by laser ablation inductively coupled plasma mass spectrometry. J Anal at Spectrom 33:231-239 